\title{
Assessment of Risk of Malnutrition in Elderly Hypertensive Patients with or without Associated Cardiovascular Risk Factors Living at Home (West Algeria) Sidi-Bel-Abbès
}

\author{
Hamza Nadjib Merad-Boudia, Karima Bereksi-Reguig \\ Département de Biologie, Faculté des Sciences de la Nature et de la Vie, Université Djilali Liabès, Sidi-Bel-Abbès, \\ Algérie \\ Email: mbhnaguib@yahoo.fr
}

Received 12 January 2016; accepted 24 February 2016; published 29 February 2016

Copyright (C) 2016 by authors and Scientific Research Publishing Inc. This work is licensed under the Creative Commons Attribution International License (CC BY). http://creativecommons.org/licenses/by/4.0/

(c) (;) Open Access

\begin{abstract}
Undernutrition is frequently underestimated in the elderly, because clinical manifestations are non-specific. For the francophone Club geriatrics and nutrition, poly medication is one of the warning signs to be the possibility of malnutrition in an elderly person. To do this, it is particularly interesting to verify what the profiles of hypertensive patients who are at risk of malnutrition are. This component remains very little explored and studies are lacking. The authors conducted a descriptive cross-sectional study whose objective is to evaluate the prevalence of undernutrition in hypertensive patients with or without associated cardiovascular risk factors, in a population of consultants of liberal medical offices, determine the profiles of hypertensive patients who are at risk of undernutrition and describe their eating habits and their anthropometric parameters as well as the link between the number of supported antihypertensives and risk of undernutrition. 1144 patients with an average age of 65 years old have been collected during the period of recruitment. The data collection was done using a questionnaire: the MNA. Sensitive and specific, it is validated method which has international sacle. The percentage of the risk of malnutrition was estimated at $\mathbf{3 6 . 7 \%}$. Thus the number of associated cardiovascular risk factors becomes larger, and the risk of malnutrition is increased. The risk of malnutrition was three times higher in patients who take more than three medications per day compared with those who consumed less (75.8\% vs. $24.2 \%)$. As a monotherapy, an increased risk of malnutrition is associated with diuretics. For these older hypertensives, the risk of malnutrition was linked to the type of used dual. The percentage of hypertension risk of malnutrition treated with free dual was significantly higher
\end{abstract}


compared to hypertensive treated dual handset. Some associations have proved to be more favorable than others in terms of nutritional risk. Finally, a third of hypertension patients who were treated with quadruple therapy were at risk of malnutrition. This work was also designed to present an argument to a doctor to detect the risk of undernutrition in elderly hypertensives. The use of the MNA is a simple, effective and quick way for pressure balance rhymes with nutritional balance.

\section{Keywords}

\section{Risk of Malnutrition, Cardiovascular, Risk Poly Medication, Older Hypertensive Mini Nutritional} Assessment

\section{Introduction}

Under the term "malnutrition", it is possible to encompass very different situations and reading the medical literature contains a large number of examples.

For the ANAES, undernutrition is the result of an imbalance between contributions and the protein-energy requirements of the body.

This imbalance leads to tissue loss with deleterious functional consequences. It's a different strictly involuntary tissue loss of weight loss which may be voluntary or not [1].

It can be global, and is called protein-energy malnutrition, or part, and in this case, it affects preferentially one or more nutrients, especially micronutrients.

In the study Euronut-Seneca conducted in 1005 elderly at 74 - 79 years old, living at home, $23.9 \%$ of men and $46.8 \%$ of women had food inadequate intake in one or more of the following micro-nutrients: calcium, iron, retinol, beta-carotene, vitamin B1, B6 or (c). [2]

The prevalence of undernutrition depends on the tools used for diagnosis and the whereabouts of the people studied.

In developing countries, it is likely to be higher, between $15 \%$ and $30 \%$, but studies currently are lack [3], especailly in the main group at risk of malnutrition, the elderly.

The analysis of these studies used to assess the extent of the phenomenon and its consequences in terms of morbidity and mortality is done.

In the elderly, undernutrition contributes to the occurrence of sometimes serious pathologies. It helped destabilize the balance of chronic diseases such as heart, kidney or respiratory failure.

Malnutrition weakens people and makes them more vulnerable: the risk of infections is therefore greatly increased, in the case of operation healing is difficult and long. Undernutrition is also responsible for muscle wasting; it is even responsible for an increase in the risk of falls.

This state also contributes to the accelerated aging and reduction of autonomy.

Malnutrition in the elderly is therefore a serious condition which weakens considerably these already vulnerable people.

Several studies have identified situations at risk of malnutrition among the elderly already considered themselves as a group at risk. Alibhai et al. [4] have done a review of the most common causes of weight loss in the elderly among them: the HTA.

According to steps wise on NCD conducted in 2003 in Algeria with 4156 people, the prevalence of hypertension was $26 \%$ [5].

Hypertension was also the most frequent morbid conditions found in $16.23 \%$ of those aged 35 to 70 years old of Tahina survey, conducted in 2005 in 4818 households [6].

Nutritional diagnosis is too often overlooked in diagnostic procedures in daily clinical practice. This is related to the lack of time or lack of knowledge of nutritional problems and their impact on the health of patients by the medical staff. Nutritional disorders are being seen as secondary to the disease causing hospitalization [7].

According to the American Society for Parenteral and Enteral Nutrition (ASPEN) [8], it is important to detect malnutrition among people aged aggressively.

The collection of clinical and biological components easily accessible and the use of simple composite indices 
provide a nutritional diagnosis satisfying to consider therapeutic step [9].

For cela experts of the national Programme nutrition santé (PNNS), as well as the European Society for Parenteral and Enteral Nutrition (ESPEN) recommend the use of the MNA test in the elderly [10] [11].

The introduction of early and appropriate nutritional support is indeed the pledge of a decrease of co-morbidities of the duration of hospital stays and hospitalization costs related to malnutrition [12].

\section{Subjects and Methods}

The main objective was to assess the prevalence of undernutrition in hypertensive patients with or without risk factors cardiovascular Associates, aged 50 years and over within the population of patients seen in medicine of city.

The survey was conducted in the town of sidi bel abbes; 01 March 2014 to 31 October 2014.

The recruitment of patients was done with medical specialists in cardiology and internal medicine.

The number of patients included in the investigation corresponds to those having consulted during this period.

\subsection{Secondary Objectives}

Determine the profiles of hypertensive patients who are a risk of undernutrition.

Describe their eating habits and their anthropometric parameters as well as the link between the number' caught antihypertensives and risk of undernutrition.

\subsection{Inclusion Criteria}

Age over 50 years for both sexes.

Hypertensive known and treated with the same therapy for at least three months.

Presence or not of one or more associated cardiovascular risk factors (diabetes or Dyslipidemia treated...).

\subsection{Exclusion Criteria}

Edemes, some either their origins, for example: If lowering of the oncotic pressure: during a cirrhosis, in case of malnutrition in a kwashiorkor, during a nephrotic syndrome by renal loss of proteins, dialysis patients and there is the drug causes: blockers, steroids and NSAIDs, causing water retention.

Patients with ascites.

Patients dehydrated.

Patients who have undergone surgery in the past 12 months.

\subsection{The Preliminary Survey}

Any investigation inevitably alters the behavior of the observer, so before you begin, the Protocol that was developed was the subject of a test on the field in order to verify that the subjects are actually available, that medical records are accessible, that questionnaires are usable and are not too long to complete, that response rates to obtain the necessary staff etc.

Improbably, this led to revise some aspects of the original Protocol (including questionnaires). Changes to the questionnaire are summed up to the replacement of the number of meals in question No 10.

How real meal the patient take per day?

Score $0=2$ meals, $1=3$ meals, $2=4$ meals.

Instead of:

Score $0=1$ meal, $1=2$ meals, $2=3$ meals.

The interest of this preliminary survey was also to treat a new dimension of the subject based on other works and readings.

By targeting appropriate patient profiles, key concepts and notions have been recorded in order to explore them and to deepen.

The mode of administration of the questionnaire was standardized for more accuracy and consistency inspired by the manual of the Mini Nutritional Assessment MNA issued by the NNI [13]. A final Protocol was then prepared. 


\subsection{Definition of Concepts}

\subsubsection{The MNA}

The data collection was done using a questionnaire: the MNA.

The MNA ${ }^{\circledR}$ was translated into over 20 languages and used in different elderly populations in several countries: hospitalized populations, preoperative, convalescing in house retirement or at home [14].

It is a method of evaluation of I' nutritional status of the elderly at risk of malnutrition, which is month expensive. fast, simple non-invasive and validated international, way, if necessary, a nutrition intervention or a correction of the diet [15].

The MNA consists of 18 items and can be done in 10 minutes or less.

II includes:

An overall assessment; an food investigation; anthropometric measures, provides information on the consumption of drugs and also subjectively evaluates the condition of health.

The Dem can be used in the form of quantitative or qualitative variable.

To meet the objectives, this scale was routinely administered in its entirety. Insofar as the MNA was viewed as a quantitative variable.

The extent of the variation of the score to the MNA was apprehended to compare scores with each other, appreciate the relationship with the possible factors of malnutrition and seize the heterogeneity of the problems.

The thresholds for risk of malnutrition were considered as qualitative variable to describe our population and establish profiles of hypertensive patients at risk of malnutrition.

The MNA is:

-More sensitive than serum albumin in the detection of those at risk of malnutrition;

-Predictive of mortality at 3 months.

Furthermore, using clinical examination as reference, the sensitivity and specificity of the MNA ${ }^{\circledR}$ were $96 \%$ and $98 \%$.

The diagnosis of malnutrition is based on anthropometric and biological criteria or the MNA score. One of these criteria is sufficient to make the diagnosis of malnutrition in the elderly

Weight loss involuntary $>5 \%$ in 3 months or $>10 \%$ in 6 months.

A BMI < 21), l' albumin < $35 \mathrm{~g} / \mathrm{l}$ and $(\mathrm{DEM}<17)[16]$.

\subsubsection{Undernutrition}

The definition of malnutrition varies according to the sources.

The Working Group of the Directorate of hospitalization and care organization (DHOS), the national programme nutrition health (PNNS) [17], as well as the European Society for Parenteral and Enteral Nutrition (ESPEN) recommend the use of the MNA ${ }^{\circledR}$ test for the detection of malnutrition in the elderly [18].

The ASPEN recommends (151), among other searching for Comorbidities, all patients, regardless of the place (home, hospital, another place of care) [19].

In accordance with the classification of the MNA, hypertensive elderly patients were split into three groups: a group having a correct nutritional status (MNA $\geq 24)$, a group with a risk of malnutrition $(17<$ MNA $<24)$ and a group with poor nutritional status (MNA $\leq 17$ ).

Then the risk group and the group with poor nutritional status were considered as one group 'at risk'. The hypertensive were therefore split into two groups:

A group having a correct nutritional status (MNA $\geq 24$ ) and a group with a risk of malnutrition (MNA $<24)$.

This grouping can be found in the literature [20] [21].

\subsubsection{Weight}

The weight measurement is essential.

It was measured with a minimum of clothing using an electronic scale (NEC France).

The latter was broad, stable and appropriate to the degree of autonomy so that the elderly can keep standing. [1].

Regular calibration of the balance was necessary, accuracy of $\pm 50 \mathrm{~g}$ [22].

Patients with ascites or edema artificially increasing body weight were systematically excluded under the exclusion criteria. 
To complete question 2 of the Dem on the recent weight loss, l es earlier variations found in the records of patients were particularly interesting.

More than the weight itself measured the day of the survey, this weight loss was an early sign of malnutrition [1].

\subsubsection{The Size}

To assess the risk of malnutrition, it is not necessary to get the size of as strictly for resuscitation [23].

The problem is that its decline with age.

The size was measured in an upright position without shoes and heels with a measuring rod.

Failing BMI was calculated from the size found on the ID card [23].

\subsubsection{BMI}

Regarding BMI, the categories defined by who were used [24] see Table 1. BMI was calculated as weight (kg) divided by the square of the height.

\subsection{Statistical Analyses}

The statistical analysis was performed on Epi info version 7. Provided several parametric tests reserved for large samples were used, inter alia, the comparison between two percentage when it comes to qualitative characters, comparison between two averages for quantitative traits.

The test of KHIDEUX of PEARSON was used after check the normality of the distribution and operating conditions.

When the latter were not met, we have processes to either of the two methods, either the grouping of classes or the correction of YATES.

Several variants of the KHIDEUX test have been used as, KHIDEUX of uniformity, the test of khideux of independence.

The FISCHER test-SNEDECOR was aimed to check the overall homogeneity of the various profiles in our sample for this:

The report of dispersal inter-groups and dispersal intra groups was calculated (to compare several averages of a quantitative trait). Simple correlation analysis was used to measure the intensity and linearity in the case of its existence between two quantitative variables (independent explanatory variable and dependent variable explainned).

The $p$ significance threshold $\leq 0.05$ is considered for all statistical analyses.

\subsection{Confidentiality, Information from Persons and Legal Provisions}

The survey received a favorable opinion on the part of participating doctors.

The anonymous questionnaires were administered with a serial number and the initials for names and first names.

It was explained to each patient who responded to the questionnaire was included as part of the history of routine in order to improve their support.

Table 1. WHO according to BMI classification [24].

\begin{tabular}{cc}
\hline BMI $\left(\mathrm{kg} \cdot \mathrm{m}^{2}\right)$ & Interpretation \\
\cline { 2 - 2 } less than 16.5 & The classes \\
16.5 to 18.5 & undernutrition or famine \\
18.5 to 25 & thinness \\
25 to 30 & normal body \\
$30-35$ & overweight \\
35 to 40 & obesity moderate \\
more than 40 & severe obesity \\
\hline
\end{tabular}


Also some issues as well as some anthropometrics settings were already respect for medical confidentiality was of course guaranteed.

\section{Results}

Thus 1144 patients have been collected during the period of recruitment. The characteristics are represented to the Table 2, Table 3.

\subsection{Individual Morbidity}

\subsubsection{Frequency of Diabetes}

Almost half of the 50 years, included hypertensives in this study, was known and treated for diabetes (regardless of the type of diabetes), this frequency was higher among women 66.66 percent men 33.33\% (Figure 1).

\subsubsection{Frequency of Dyslipidemia}

Amongst the hypertensive constituting our sample, almost two patients on five were dyslipidemic (37.76\%) (Table 4), sex, this frequency was nearly two times more increased among women (72.22\%) compared to men (27.77\%) (Figure 2).

Table 2. Characteristics of the study population.

\begin{tabular}{|c|c|c|c|c|}
\hline & Men & Women & Total & Statistical parameters \\
\hline & $(440)$ & $(704)$ & (1144) & \\
\hline \multicolumn{5}{|l|}{ Sex ratio } \\
\hline$(\mathrm{f} / \mathrm{h})$ East of 1.6 & $38.5 \%$ & $61.5 \%$ & & \\
\hline Age & $65.88 \pm 9.65$ & $65.49 \pm 9.88$ & $65.26 \pm 9.93$ & $\varepsilon_{c}=1.16$ \\
\hline Weight & $75.44 \pm 12.51$ & $75.30 \pm 12.58$ & $75.33 \pm 12.62$ & $\begin{array}{c}\mathcal{E}_{\mathrm{c}}=0.18 \\
\mathrm{CV}=0.16\end{array}$ \\
\hline The size & $168.8 \pm 6.58$ & $168.1 \pm 7.14$ & $168.1 \pm 7.18$ & $\begin{array}{c}\varepsilon_{\mathrm{C}}=1.69 \\
\mathrm{CV}=0.04\end{array}$ \\
\hline IMC & $26.62 \pm 4.12$ & $25.64 \pm 4.27$ & $25.64 \pm 4.27$ & $\varepsilon_{\mathrm{C}}=0.08$ \\
\hline \multicolumn{5}{|c|}{ Brachial circumference } \\
\hline \multirow[t]{2}{*}{$\mathrm{CB}<21$} & 8 & 12 & 20 & $\mathrm{Chi}^{2}=0.36$ \\
\hline & $1.81 \%$ & $1.7 \%$ & $1.7 \%$ & $\mathrm{DDL}=2$ \\
\hline \multirow[t]{2}{*}{$21 \leq \mathrm{CB} \leq 22$} & 24 & 36 & 60 & $\mathrm{p}=0.38$ \\
\hline & $5.45 \%$ & $5.11 \%$ & $5.24 \%$ & $\mathrm{CV}=0.16$ \\
\hline \multirow[t]{2}{*}{$\mathrm{CB}>22$} & 408 & 656 & 656 & \\
\hline & $92.72 \%$ & $93,18 \%$ & $93 \%$ & \\
\hline \multicolumn{5}{|l|}{ Calf circumference } \\
\hline \multirow[t]{2}{*}{$\mathrm{CM}<31$} & 60 & 72 & 132 & $\mathrm{Chi}^{2}=2.91$ \\
\hline & $13.63 \%$ & $10.22 \%$ & $11.53 \%$ & $\mathrm{DDL}=1$ \\
\hline \multirow[t]{2}{*}{$\mathrm{CM} \geq 31$} & 380 & 632 & 1012 & $\mathrm{p}=0.41$ \\
\hline & $86.36 \%$ & $89.77 \%$ & $88.46 \%$ & \\
\hline
\end{tabular}

Table 3. Frequency of diabetes.

\begin{tabular}{|c|c|c|c|c|c|c|}
\hline \multirow{2}{*}{ Disease state } & \multicolumn{2}{|c|}{ Men } & \multicolumn{2}{|c|}{ Women } & \multicolumn{2}{|c|}{ Total } \\
\hline & $\mathrm{n}$ & $\%$ & $\mathrm{n}$ & $\%$ & $\mathrm{n}$ & $\%$ \\
\hline Diabetic & 200 & 33.33 & 400 & 66.66 & 600 & 52.44 \\
\hline Non-diabetic & 240 & 44.11 & 304 & 55.88 & 544 & 47.55 \\
\hline Total & 440 & & 704 & & 1144 & $100 \%$ \\
\hline
\end{tabular}




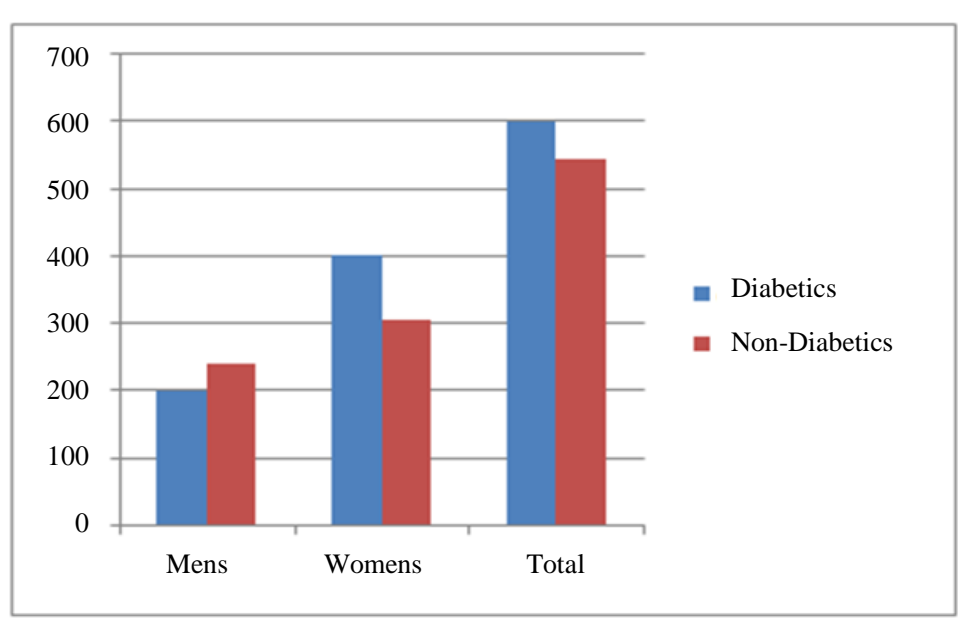

Figure 1. Frequency of diabetes.

Table 4. Frequency of dyslipidemia.

\begin{tabular}{|c|c|c|c|c|c|c|}
\hline \multirow{2}{*}{ Disease state } & \multicolumn{2}{|c|}{ Men } & \multicolumn{2}{|c|}{ Women } & \multicolumn{2}{|c|}{ Total } \\
\hline & $\mathrm{n}$ & $\%$ & $\mathrm{n}$ & $\%$ & $\mathrm{n}$ & $\%$ \\
\hline Dys lipidemique & 120 & 27.77 & 312 & 72.22 & 432 & 37.76 \\
\hline Not dyslipidemique & 320 & 44.94 & 392 & 55.05 & 712 & 62.23 \\
\hline Total & 440 & & 704 & & 1144 & $100 \%$ \\
\hline
\end{tabular}

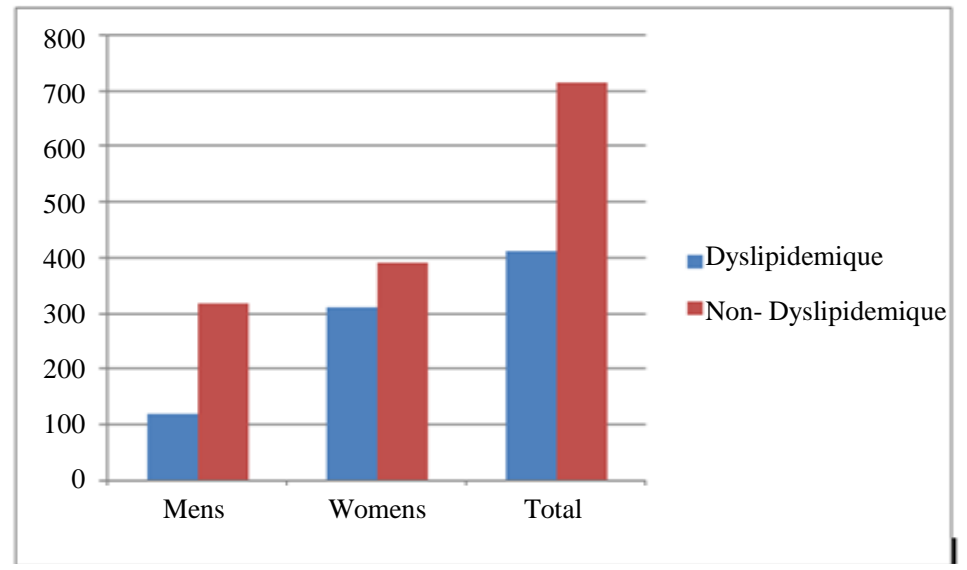

Figure 2. Frequency of dyslipidemia.

\subsection{Distribution of Patients According to Anti Hypertensive Therapy}

The distribution of patients was significantly different according to antihypertensive therapy, $\left(\mathrm{Chi}^{2}=26.85\right.$, ddl = 4) (Table 5), almost 2 patients on five were treated by one (41\%) or two antihypertensive drugs (42.65\%). Furthermore, $12.93 \%$ of the patients were treated by three antihypertensives and only 3.5\% by a four.

It was also quite interesting to see what items the hypertensive elderly lost points in the MNA (Table 6).

Firstly, the rather positive items to their nutritional status.

Mean BMI was $25.64 \pm 4.27$ corresponding to a "normal” said index, at the limit of overweight.

In other words, the majority of hypertensive elderly presents a quite correct body and does not seem thin (even as table above).

The hypertensive elderly in our sample appear to have proper food consumption, since 66.1\% consume, at least once a day, dairy products, 1 - 2 times per week, eggs or legumes and 73.1\% consume, at least twice a day, 
Table 5. Distribution of patients according to the anti hypertensive therapy.

\begin{tabular}{|c|c|c|c|c|c|c|c|}
\hline \multirow{2}{*}{\multicolumn{2}{|c|}{ Anti hypertensive therapy }} & \multicolumn{2}{|c|}{ Men } & \multicolumn{2}{|c|}{ Women } & \multicolumn{2}{|c|}{ Total } \\
\hline & & $\mathrm{n}$ & $\%$ & $\mathrm{n}$ & $\%$ & $\mathrm{n}$ & $\%$ \\
\hline \multicolumn{2}{|c|}{ Monotherapy } & 180 & 41 & 288 & 41 & 468 & 41 \\
\hline \multirow{2}{*}{$\begin{array}{l}\text { Dual therapy } \\
\text { total (488) }\end{array}$} & BI-free & 128 & 29 & 128 & 18.18 & 256 & 22.37 \\
\hline & BI-combinee & 64 & 14.54 & 168 & 23.86 & 232 & 20.27 \\
\hline \multicolumn{2}{|c|}{ Triple therapy } & 52 & 11.81 & 96 & 13.63 & 148 & 12.93 \\
\hline \multicolumn{2}{|c|}{ Four } & 16 & 3.63 & 24 & 3.4 & 40 & 3.5 \\
\hline
\end{tabular}

Table 6. The positive items for their nutritional status to the MNA.

\begin{tabular}{ll}
\hline BMI greater than or equal a 23 & $84.26 \%$ \\
BMI between 21 and 23 & $8.74 \%$ \\
BMI between 19 and 21 & $3.84 \%$ \\
BMI less than 19 & $3.14 \%$ \\
Brachial circumference greater than 22 centimeters & $93.00 \%$ \\
Circumference of the calf longer than 31 cm & $88.46 \%$ \\
No weight loss over the last three months & $71.4 \%$ \\
Showed no disease acute or psychological stress during the last three months & $61.88 \%$ \\
Do not have pressure sores or skin wounds & $90.90 \%$ \\
\hline
\end{tabular}

fruit and vegetables.

Moreover, it seems that this is not dependence for feeding that average is associated with loss of points to the MNA.

In fact, only $1.9 \%$ need assistance for food. $2.8 \%$ feed alone, but with difficulties and $95.3 \%$ feed only without difficulty.

De plus, $72.3 \%$ consider themselves without specific nutritional problems.

All the other items that make lose points in the MNA, entirely due to the weaknesses related to the pathology poly.

First of all, $86.7 \%$ of they consume more than three drugs per day.

Only $52.1 \%$ are four meals a day, 35.4\% take three meals a day, $8.2 \%$ two meals and only $4.3 \%$ one meal per day. Moreover $11.8 \%$ take more than 5 glasses of drink per day.

These items are fairly characteristic of the population consuming a large number of medicines that tends a little hydrated and take less meals, including one for the night.

Furthermore, nearly $60 \%$ of hypertensive elderly presented recent loss of appetite, which may be associated with a high consumption of drugs, but also has other factors: problems digestive difficulty chewing or swallowing, recent surgery.

Thus 1144 patients have been collected during the period of recruitment. The characteristics of the patients are given in the table.

The percentage of the risk of malnutrition was estimated a 36.7\% which corresponds to a 21.2 average DEM $2.32 \pm$ which varies between a minimum of 11.5 (severe malnutrition) and a maximum of 23.5 malnutrition threshold selected scale MNA.

The average age of the hypertensive risk of malnutrition is of $67.95 \pm 6.22$ Males $68.54 \pm 6.38$ and women $67.66 \pm 6.19(\varepsilon=1.35, \mathrm{p}=0.18>0.05)$.

No significant difference ( $\mathrm{p}>0.05$ ) were observed between the age of women and men with age values centered around the average for both sexes $(\mathrm{C} . \mathrm{V}$ men $=0.093$ and $\mathrm{C} . \mathrm{V}$ women $=0.091$ )

Thus, half of the men at risk of malnutrition have an age between 59 and 77 years old and half of women at risk of malnutrition have an age between 60 and 74 years (Figure 3). 


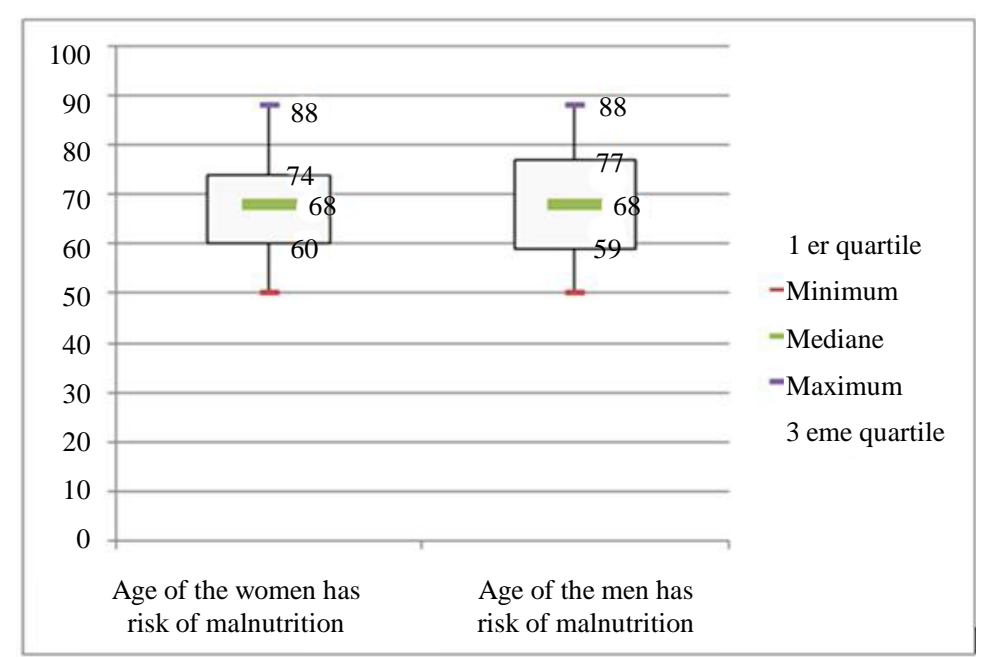

Figure 3. Age of hypertension at risk of malnutrition.

The average MNA of men at risk of malnutrition is $21.26 \pm 2.28$ Women's equal average MNA has $21.18 \pm$ 2.32 .

The risk of malnutrition was significantly related to sex (Chi-square $=7.67, \mathrm{ddl}=1, \mathrm{p}=0.003)$; higher among women $39.77 \%$ Vs $31.81 \%$ for men.

ANM score going in the women at risk of malnutrition of 19.5 in the first quintile to 23 in the last and among men by 19 in the first quintile was 23.5 last $(\mathrm{p}<0.001)$.

The MNA allowed screening for hypertension a risk of malnutrition before even the decline in BMI, brachial circumference, the circumference of the calf and without same there is weight loss (Figure 4).

Thus, among the $36.7 \%$ of hypertensive has risk of malnutrition: $85.71 \%$ have upper brachial circumference was 22 and 78.09\% have a circumference greater than or equal calves has 31. Through elsewhere, weight loss were observed for $23.8 \%$ during the previous three months.

According to the classification who, $100 \%$ of patients who have a BMI less than 18.5, thinness and extreme thinness stage are also tracked by the MNA.

For a BMI greater than or equal a 18.5 (normal or more) more than $97.14 \%$ are considered at risk of malnutrition by the MNA.

Finally, for $71.4 \%$ was not there a weight loss over the last three months.

The percentage of hypertension risk of malnutrition with a circumference brachial inferior to 21 was very high: $80 \%$.

In addition, found hypertension risk of malnutrition, $100 \%$ of them who had the most mediocre MNA (equal to 11.5) had among other a circumference brachial inferior to 21 (Figure 5).

The risk of malnutrition was five times higher in hypertensives that have a circumference brachial inferior has 22 Odds ratio OR 5.86, CI 95\% = [3.48, 9.88].

The percentage of hypertension risk of malnutrition with a circumference of calves less than 31 was two times higher compared with those who had a circumference of the calf greater than or equal to the same value (Figure 6).

The risk of malnutrition was more than four times higher in hypertensives who have a lower calf circumference a 31 Odds ratio $=\mathrm{OR}=4.79,95 \% \mathrm{CI} \%=[3.23,7.11]$.

Correlation analysis showed that the risk of malnutrition and the age range in the same direction (cov (risk age $)=4.48)$ but the correlation coefficient was low $(r=0.14)$ then it seems that several confounding factors can interact:

At a very advanced age of hypertensive treated monotherapy may be neither diabetic nor dyslipidemic, while older hypertensive of 65 for example can be treated with an anti hypertensive therapy; Therefore it is difficult to interpret these results.

On the practical level, to work around this problem and meet the objective main risk of malnutrition was appreciated on several components: 


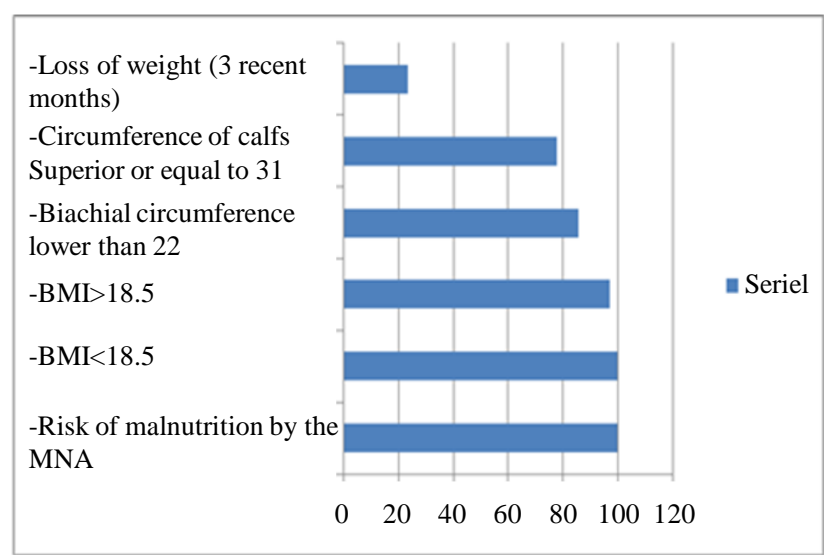

Figure 4. Sensitivity of the MNA compared with anthropometric parameters (as a percentage).

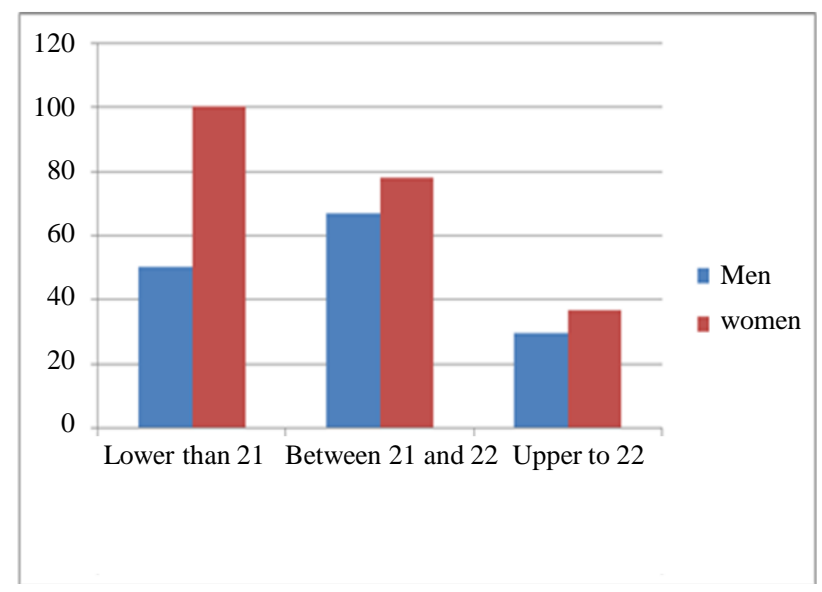

Figure 5. Risk of malnutrition and brachial circumference (in percentage).

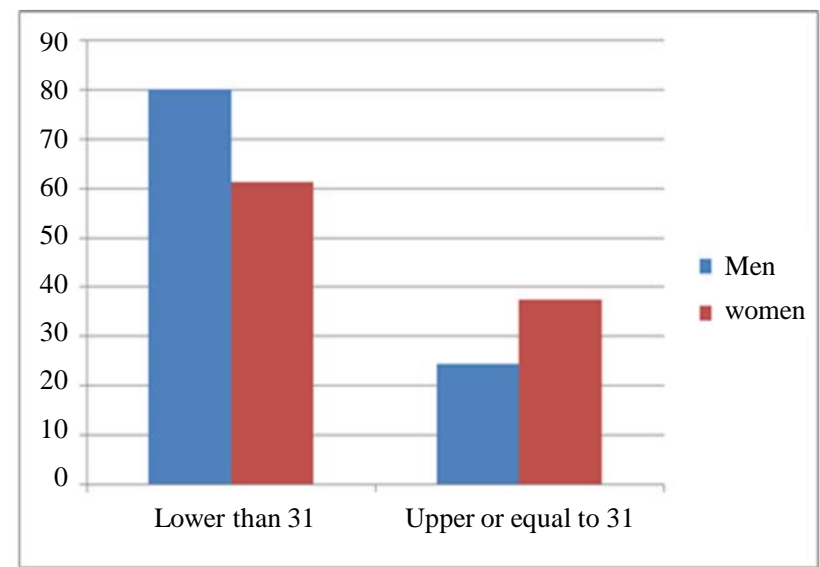

Figure 6. Risk of malnutrition and circumference of the calf (in percentage).

Assess the relationship between the number of drugs taken by day and risk of malnutrition and poly medication (Item 8 of the MNA questionnaire).

Evaluate the risk of malnutrition according to each strategy anti hypertensive (monotherapy, dual, triple, and 
four), and finally evaluate cardiovascular risk.

Thus more cardiovascular risk factors there, more risk of malnutrition is increased (Table 7) (Figure 7).

The presence of diabetes and hypertension at the same time is very common. The PROCAM study the prevalence of hypertension in diabetics is 50\% [84].

\subsection{Poly Medication and Risk of Malnutrition}

The risk of malnutrition was not the same in both groups $(\varepsilon \mathrm{c}=3.9)$.

According to Figure 8, it was three times higher in patients who take more than three medications per day compared with those who consumed less. $(75.8 \%$ Vs $24.2 \%)$ OR $=3.00,95 \%$ CI \% $=[2.26,3.99]$.

\subsection{Risk of Malnutrition and Anti Hypertensive Therapy}

\subsubsection{Monotherapy}

The average age of the hypertensive risk of malnutrition treated in monotherapy was 67.64 years \pm 10.24 (67 years and 8 months) with an average dem of $21.40 \pm 1.93$. (MNA $\min =16$, MNA $\max =23.5$ ).

Table 7. Risk of malnutrition and cardiovascular risk.

\begin{tabular}{cccc}
\hline & Dyslipidemiques non diabétics & diabétics non dyslipidemiques & Diabétics and dyslipidemiques \\
\hline Risque of malnutrition & $24(5.71 \%)$ & $88(20.95 \%)$ & $132(31.42 \%)$
\end{tabular}

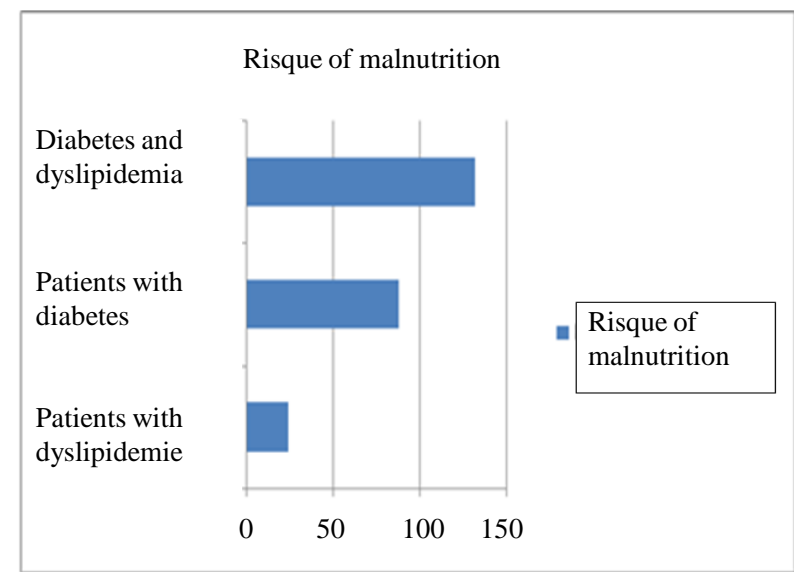

Figure 7. Analysis of correlation between age and the risk of malnutrition.

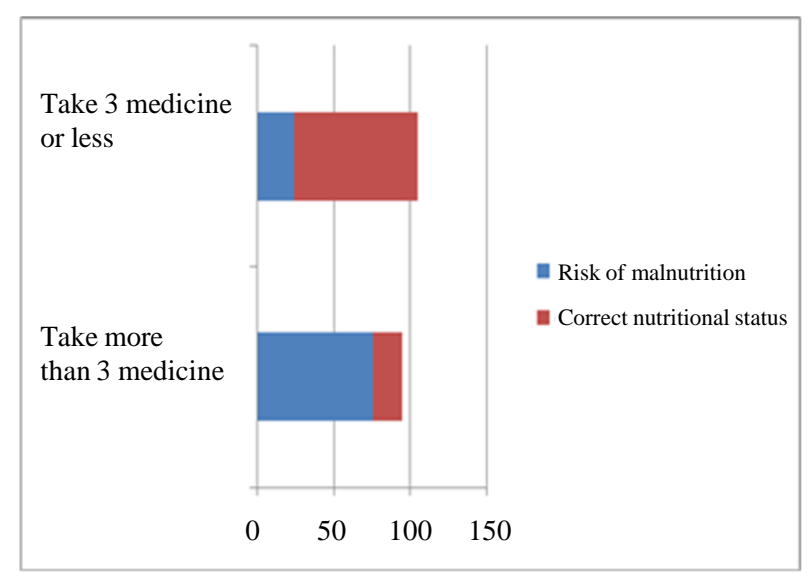

Figure 8. Risk of malnutrition and poly medication. 
The risk of malnutrition in hypertensives treated monotherapy was significantly different between the five classes of antihypertensive agents recovered (Chi-square $=19.02$, $\mathrm{ddl}=4$ ).

Hypertension treated with a diuretic monotherapy, $60 \%$ of them were at risk of malnutrition with an average score of the most mediocre MNA of $19.95 \pm 0.69$ (Nam $\min =19 \max =21$ MNA) and little variation in the same group $(\mathrm{CV}=0.034)$ (Figure 9).

Concerning the distribution of patients at risk of malnutrition in monotherapy according to age and score average MNA:

In the group treated with a beta-BLOCKER monotherapy, the risk of malnutrition was lower: $28.57 \%$ with a score average MNA of $20.95 \pm 1.74$.

On the other hand, with a risk of malnutrition by 33\%, hypertension treated with an ANGIOTENSIN 2 receptor ANTAGONIST appeared to have an average dem approaching the correct nutritional status with 22.21 more \pm 1.11 (DEM 20 min and a max of 23.5 DEM) (Table 8) and less significant variations compared to the Group of hypertensive patients under beta BLOCKER:

$(\mathrm{CV}=0.049$ for the ANTAGONIST of RECEPTORS of the ANGIOTENSIN $2 \mathrm{Vs} \mathrm{CV}=0.083$ to the beta-BLOCKER).

\subsubsection{Risk of Malnutrition and Total Dual: (Free Dual + Dual Combined Therapy)}

The average age of treated dual hypertension risk of malnutrition was 67.66 years \pm 10.20 (67 years and 7 months) with an average 21.13 DEM \pm 2.32 . (MNA min $=11.5$, MNA max $=23.5$ ) (Figure 10).

The risk of malnutrition was linked to the type of combination therapy used.

The percentage of hypertension risk of malnutrition in free combination therapy was significantly different compared to hypertensive treated combined dual: $(39 \%$ vs. $32.7 \%)$. (Chi-square $=4.14, \mathrm{ddl}=1)$.

Free Dual

Analysis of the risk of malnutrition in hypertensives treated dual in each of the two strategies has seemed us particularly interesting.

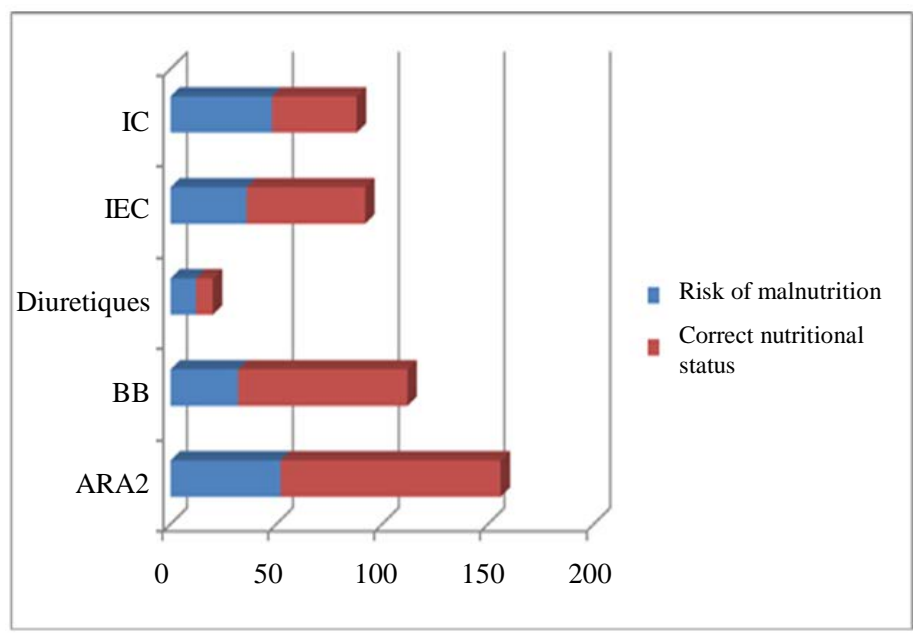

Figure 9. Risk of malnutrition and anti hypertensive therapy.

Table 8. The distribution of patients at risk of malnutrition as monotherapy according to the age and the average dem score.

\begin{tabular}{cccccc}
\hline Classes & MNA average & S.D & MNA min & MNA Max & C.V \\
\hline ARA2 & 22.21 & 1.11 & 20 & 23.5 & 0.049 \\
BB & 20.95 & 1.74 & 16.5 & 23.5 & 0.083 \\
Diuretics & 19.95 & 0.69 & 19 & 21 & 22.5 \\
IEC & 20.58 & 1.31 & 17.5 & 23.5 & 0.034 \\
IC & 21.07 & 1.87 & 16 & & 0.063 \\
\hline
\end{tabular}




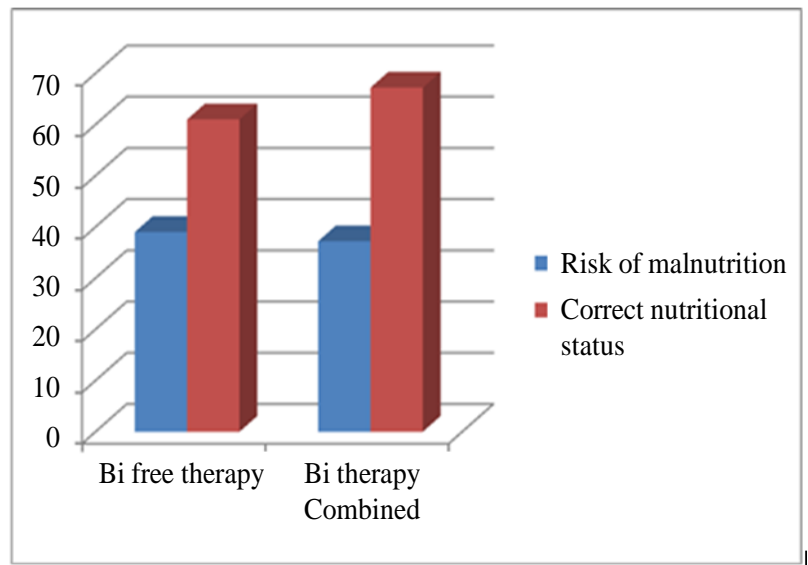

Figure 10. Risk of malnutrition and total dual: (free dual + combined dual).

In the management of hypertension in boat form, the authors compared the association IC and others with diuretics and other associations: it seems that the way of the IC (shown in blue in the figure below) is better because the percentage of other hypertension risk of malnutrition under association IC does not exceed the $50 \%$ unlike the associations with diuretics.

For hypertension treated with a diuretic (having the highest risk of malnutrition in monotherapy and the poorer MNA) associated with an IC, an INHIBITOR of the converting ENZYME, an ANTAGONIST of RECEPTORS of the ANGIOTENSIN 2 or beta-BLOCKER risk of malnutrition was greater than or equal to $50 \%$ (Figure 11).

Furthermore, in terms of percentage the two associations: INHIBITOR of the ENZYME from converting/IC (represented in red) and ARA/beta-BLOCKER are equal with $25 \%$ of hypertensive risk of malnutrition each, but the latter is not recommended by the Haute Autorité de santé.

In the group or they are associated one another, beta BLOCKER and diuretic, the risk of malnutrition was $\max ($ a $100 \%$ ) with an average dem $=19 \pm 0.00$.

Conversely for hypertension treated with a beta-BLOCKER (with a risk of the lowest malnutrition monotherapy) associated to the other classes of antihypertensive drugs risk was strictly less than a $50 \%$ Free, free dual beta-BLOCKER and diuretic-treated groups are all at risk of malnutrition below 30\% (represented in red in the boat Figure 12).

\section{Combined Dual}

In the group treated the percentage of hypertension free dual risk of malnutrition as antagonist of angiotensin 2/diuretic (shown in blue) was almost twice and a half higher has that handled dual combined by the same association $75 \%$ Vs $31 \%$ ) Odds ratio OR $=6.69$, CI 95\% $=[2.06,21.73]$ (Figure 13).

Similarly, the percentage of hypertension a risk of malnutrition treated by the association INHIBITOR of the ENZYME of CONVERSION/diuretic (shown in blue in Figure 11) free dual was three times higher than treated dual combined by the same association (60\% Vs 20\%) (Figure 14) Odds ratio OR $=6$, CI 95\% $=[1.45,24.68]$.

Conversely, the percentage of hypertension a risk of malnutrition treated by the association (represented in red, Figure 15) ICA/ANGIOTENSIN receptor ANTAGONIST2 free dual seems less has the group treated by the same association combined dual (29.4\% vs. $45.5 \%)$ but this hypothesis remains to be confirmed because the Ods ratio was not for a true association between uses it has a dual free or combined and a possible risk of malnutrition (Figure 16) Odds ratio OR $=1.1$, CI 95\% $=[0.53,2.26]$.

\subsubsection{Triple Therapy}

Among the hypertensive patients who were treated by a triple (average age of $68 \pm 10.24$ ). $35.13 \%$ were at risk of malnutrition with an average dem $=21.13 \pm 2.12$ (DEM min14 and DEM max $=23.5$ ).

92 patients $(62.16 \%)$ among those under antihypertensive therapy, showed a combination recommended by the HAS: IC with converting ENZYME INHIBITOR or ARBS or beta BLOCKER + thiazide diuretic (Which are respectively $5.4 \%, 56.75 \%$ and $0 \%$ with the beta BLOCKER). 


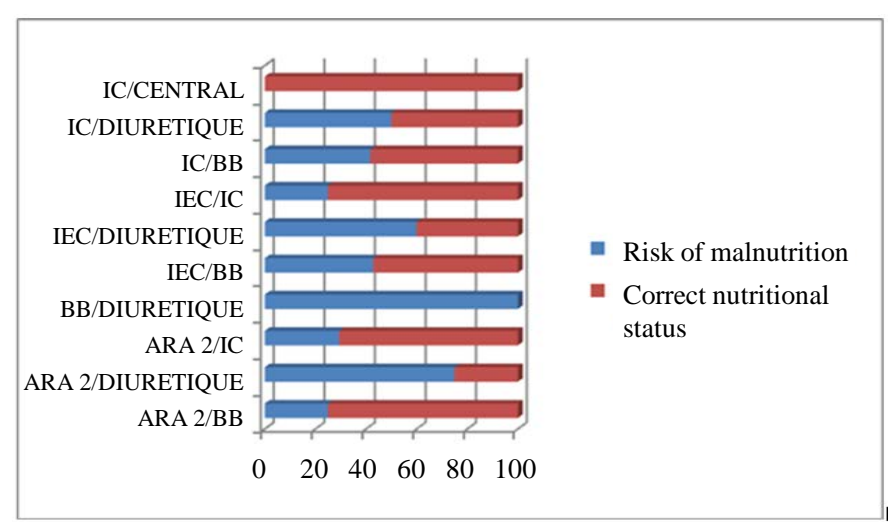

Figure 11. Risk of malnutrition and free dual.

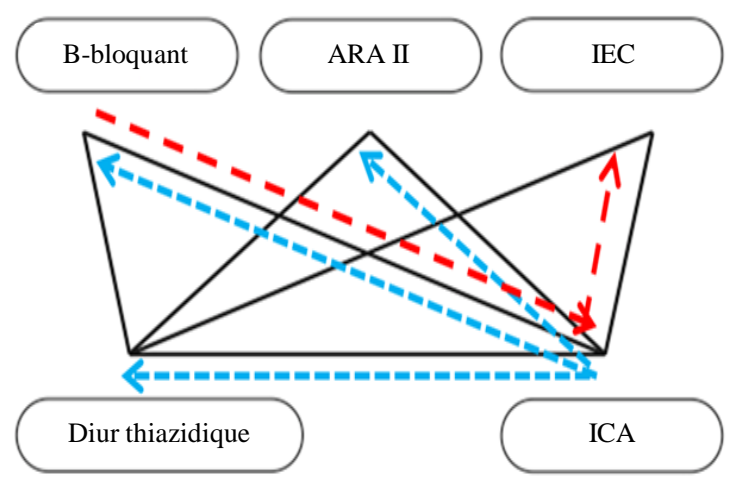

Figure 12. The possible combinations of antihypertensives which has the risk of the lowest malnutrition in the elderly hypertensive.

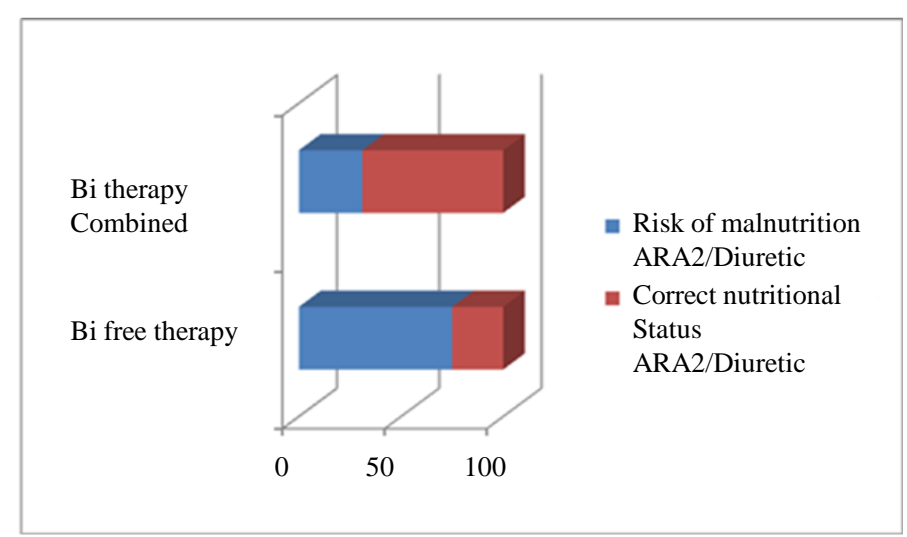

Figure 13. Risk of malnutrition and combined bitherapy (ARA2/ diuretic).

The percentage of hypertension risk of malnutrition for the first combination (INHIBITOR of CONVERSION the of ENZYME/IC/DIURETIC) was zero, but the number of patients was insufficient to infer a any conclusion ( $0.7 \%$ of all patients in the study).

In the second combination (ARA DIURETIC-IC-2) the percentage of malnutrition was of 33.33\%.

Less while the triple: (ARA 2/BETA-BLOCKER/DIURETIC) which was $50 \%$ or even triple therapy (ARA $2 / \mathrm{IC} / \beta$-BLOCKER) which was $66.7 \%$.

Finally, it seems to us that the combination recommended by the HAS (diuretics thiazide and inhibitor calcium) basket 2 including 2 of basket 1 ANGIOTENSIN receptor ANTAGONIST was also the best in terms of 
risk of malnutrition with an average dem which is close to the application of more than one nutritional state correct (see table below), and that the abandonment of the thiazide diuretics or calcium inhibitor increases see double the percentage of hypertension a risk of malnutrition.

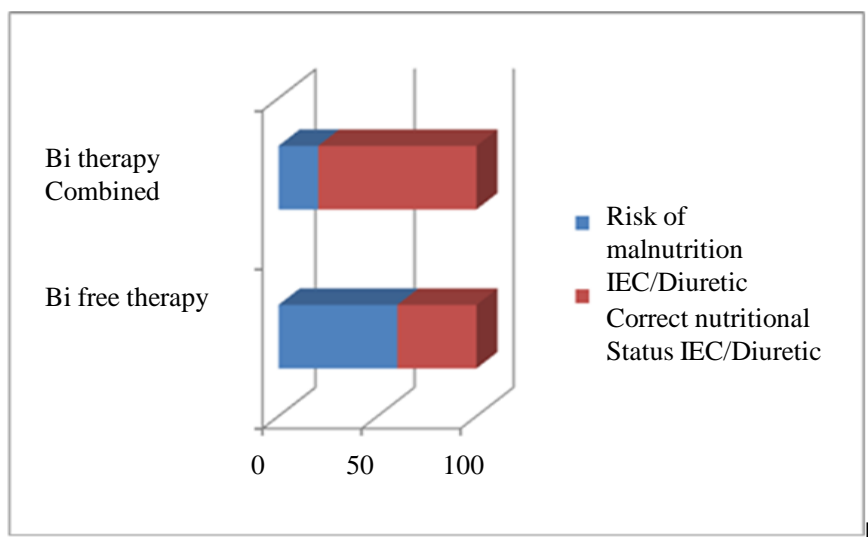

Figure 14. Risk of malnutrition and combined bitherapy (conversion/diuretic enzyme inhibitor).

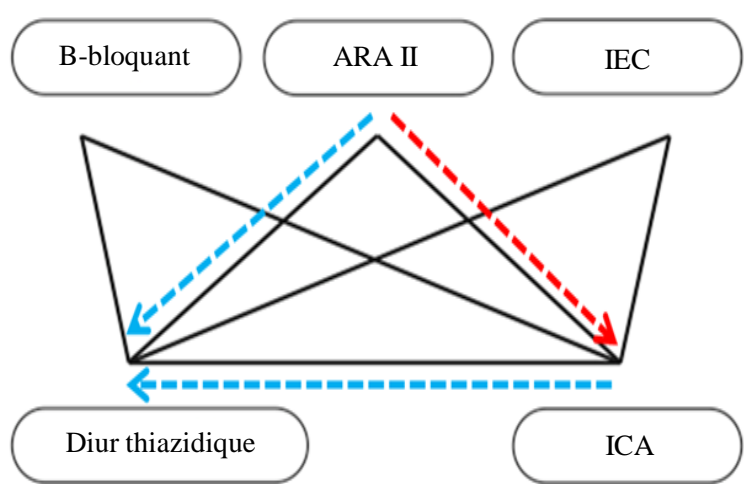

Figure 15. The possible combinations of antihypertensives which has the risk of the lowest malnutrition in hypertensive elderly subjects (combined dual vs free dual).

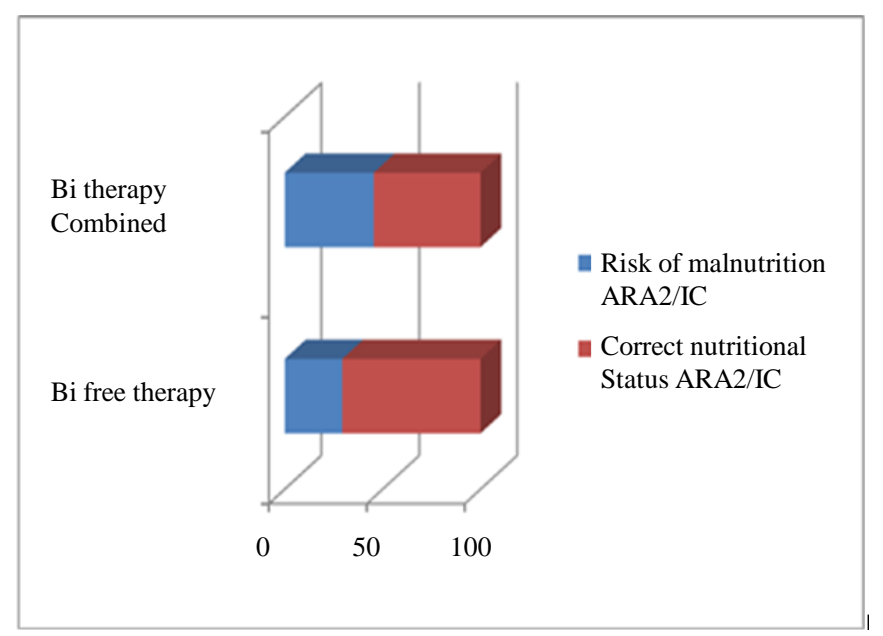

Figure 16. Risk of malnutrition and combined bitherapy (ARA2/ blocker). 


\subsubsection{Four Therapy}

$30 \%$ of hypertension who were treated by a four therapy were at risk of malnutrition with an average DEM = $22.03 \pm 1.26$ (MNA $\min 19=$ and MNA max $=23.5$ ).

In this same group $33.33 \%$ of them had less than 55 years with all a Dem of 23.5.

While $66.66 \%$ of them had over 70 years with an average dem of $20.58 \pm 0.72$ (The lowest MNA: 21.40 average $\mathrm{DEM} \pm 1.93$ monotherapy, an average 21.13 MNA \pm 2.32 in combination therapy, and an average dem = $21.13 \pm 2.12$ in triple therapy).

What got us arrested, it is that all these hypertensives treated with a four that were a risk of malnutrition had diabetes or Dyslipidemia, the presence of a resistant hypertension, or other risk factors and the increase in arterial stiffness with age which justify the use has other additional antihypertensive agents for controlling these patients is probably a tipping their nutritional status.

\subsection{Risk of Malnutrition and Protein Consumption}

$28.3 \%$ of hypertensive patients who consumed the three categories of foods recommended were at risk of malnutrition versus $67.3 \%$ who had a correct nutritional status.

This percentage increases in hypertensives who consumed less than three categories of foods: $37.8 \%$ and $39.1 \%$ for those who consumed one or two categories of foods) but it has not put in evidence a statistically significant link between the quality of food consumed and the risk of malnutrition. Odds ratio Odds ratio OR $=1.24,95 \%$ CI \% $=[0.91 ; 1.69]$.

\subsection{Risk of Malnutrition and Consumption of Fruits and Vegetables}

The percentage of hypertension risk of malnutrition was twice more in hypertensives who did not eat at least twice per day of fruits or vegetables compared with those who consumed Odds ratio Odds ratio OR $=3.23$, 95\% CI \% $=[2.46 ; 4.23]$.

The average MNA of hypertension who ate no fruit and vegetables and who were a risk of malnutrition was $21.18 \pm 2.33$, it varies little in the same group $(\mathrm{CV}=0.11)(\mathrm{Min}=11.5$ and MNA max $=23.5)$.

While the average MNA of hypertension who ate fruits and vegetables and who were risk of malnutrition was $21.25 \pm 2.01$, it varies little in the same group $(\mathrm{CV}=0.09)($ MNA $\min =15$ and MNA $\max =23.5)$.

Moreover, there in Group consumer of fruit and vegetables at risk of malnutrition, about three times less hypertensives to poor MNA $\leq 18$ (6.55\% in consumer Vs $20.45 \%$ in the non-consumer group).

\subsection{Consumption of Drinks}

The percentage of hypertension risk of malnutrition that consumed less than three glasses a day (average dem $21.18 \pm 2.33$ ) was once and a half higher than hypertension risk of malnutrition that consumed more than five glasses (Average dem $21.25 \pm 2.13$ ).

But it was difficult to establish a link between the amount of drinks consumed daily and risked malnutrition. Odds ratio Odds ratio $\mathrm{OR}=1.07,95 \% \mathrm{CI} \%=[0.73,1.55]$.

On the other hand, the percentage of hypertension has risk of malnutrition to poor MNA $\leq 18$ (severe undernutrition) past of $13.72 \%$ among those who consumed less than three glasses was $11.90 \%$ among those who consumed between three and five glasses then has $8.33 \%$ among those who consumed more than five glasses a day.

The average dem found varied little within the three groups.

$\mathrm{CV}=0.11$ for those who consumed less than three glasses a day.

$\mathrm{CV}=0.08$ for those consuming between three and five glasses per day.

$\mathrm{CV}=0.10$ for those consuming more than five drinks per day.

\section{Discussion}

Protein-energy malnutrition is frequently underestimated in the elderly, because clinical manifestations are non-specific. However all systematic studies had its high frequency in geriatrics, whatever the context of care and place of life.

The literature gives a frequency of the risk of malnutrition which can reach $25 \%$ - 30\% [27] [28] until same 
58\% [29] from 10.8\% (between 60 and 69 years) to 22\% (between 70 and 79 years) p our population aged cardiovascular risk.

The survey shows that $3.14 \%$ of elderly hypertension a risk cvs are malnourished and $36.7 \%$ of them are a risk of undernutrition.

Large epidemiological studies European (Euronut-SENECA) [25] Or American (NHANES) show that approximately $4 \%$ of seniors living at home are undernourished [26].

The prevalence of undernutrition is variable depending on the populations studied (the elderly living at home, institutionalized or hospitalized) and used tools (Anthropometry, the weight loss recent, or composite tools such as the Mini Nutritional Assessment).

However, large scale studies with a valid tool (MNA) in populations older hypertendue in medicine of city are still rare.

Although the factors related to the patient such as addiction [30] [31].

The decline of appetite [30] is known to be associated with malnutrition, much less is known about the impact of chronic diseases such as hypertension and poly medication on malnutrition.

Thus adult component sample of the TAHINA study carried out in 2005 in Algeria, 25.87\% chronic pathologies are represented by high blood pressure. Then come the diabetes (12.89\%), asthma (8.30\%), and rheumatism (8.28\%).

Furthermore, the sample consists of patients followed for chronic diseases in medicine of city, thus it is not possible to report them to the general population, or to calculate prevalence.

With regard to a first survey of its kind, there is no reference in Algeria or elsewhere to assess the extent of the problem.

However, it appears clearly in the light of the results that undernutrition is a major problem in the hypertensive population of Sidi Bel Abbes.

The thresholds used to define the population of elderly ranged [18] [32] [33].

Recruited patients were over 50 years old with an average age of 65 . Several authors worked on the same age group [34]-[36].

The most important mortality, cardiovascular mortality and hypertension risk factor is age. The risk of developing an HTA at age 65 is more than $90 \%$ in the Framingham study [37].

Women are the most vulnerable; the risk of malnutrition beyond 50 years is about $40 \%$.

This very high risk could be estimated because of the higher life expectancy of women compared to men. those ci are over-represented in the population.

In the study of suominen the study population was composed of 19.3 per cent men and $80.7 \%$ of women [38]. In de Ventose R, latter equaled 173 recruits on a total of 250 [39].

Large-scale epidemiological studies propose the BMI for the estimation of the cardiovascular risk [40].

This report is also selected as one of the criteria diagnostic of malnutrition in the elderly by several learned societies the ESPEN [41], the francophone Club geriatrics and nutrition [33] the Anaes [1] and also in studies of mortality and morbidity related to undernutrition [42] [43].

For a BMI greater than or equal a 18.5 (normal or more) more than nine hypertensive ten are considered at risk of malnutrition by the MNA.

This last was recognized more sensitive than the use of BMI and serum albumin for the detection of persons at risk of bad nutrition [44].

Poly pathology is one of the most common causes of unintentional weight in elderly loss: [4].

The results show that there are more (diabetes, Dyslipidemia) associated cardiovascular risk factors, the risk of malnutrition is increased.

The pathology poly leads to a poly medication.

The drug abuse concerns not only the number of drugs but also their dosages [45]. This component has not been addressed in the MNA.

These patients are the main victims of the drug supply: it is very frequent and severe, as responsible for a sizeable hospitalization rate \%), with a morbidity, mortality and consequences in terms of loss of autonomy [46].

The risk of malnutrition was multiplied by three for the hyeprtendus who took three prescription drugs or more (reasonable indication for the presence of co-morbidity).

For the francophone Club geriatrics and nutrition [47].

Poly medication, is also one of the 12 warning signs to be the possibility of undernutrition. 
Despite this, the HYVET study [48] the largest study ever conducted on elderly patients and hypertensive demonstrates for the first time the beneficial effect of antihypertensive treatment even after 80 years to reduce total mortality and cardiovascular events.

The purpose of the treatment of arterial hypertension in the elderly patient is not only to bring back to normal blood pressure figures. It is important also to avoid a deterioration of the nutritional status.

In the journal of Alibhai et al. [4] these treatments appear as one of the most common causes of unintentional weight loss, in accordance with the recommendations of the ESPEN [41].

It thus proposes to search for possible disorders endocrine and pathologies cardiovascular to detect the risk of malnutrition the elderly [56].

A cohort of 4714 people over 65 living at home (Cardiovascular Health Study) was monitored for 3 years [49]. Among men, $16.2 \%$ have lost more than $5 \%$ of their body weight during the 3 years of follow-up, and $4.1 \%$ have lost more than $10 \%$.

Among women, $18.7 \%$ have lost more than $5 \%$ and $6.3 \%$ have lost more than $10 \%$.

Compared to those who have maintained a stable weight, those who lost weight were older, more often had such pathologies.

What coronary artery disease, diabetes... and took more drugs.

Meta-analysis of Staessen et al. Published in 2000 [50] includes 8 test results (SHEP, Syst-Eur, Syst-China, EWPHE, HEP, STOP and MRC1, MRC2). It covers more than 15,000 patients 60 years of age and more and finds that a reduction in no $10 \mathrm{~mm} \mathrm{Hg}$ would allow a reduction of $26 \%$ of deaths all-cause mortality, $22 \%$ of the risk of stroke and $7 \%$ of coronary events.

This amounts to reduce the risk of a possible unintentional weight loss directly related to the risk of malnutrition [4] [41].

So it is particularly interesting to check what are the patterns of hypertensive patients who are at risk of malnutrition? This component remains very little explored and studies are lacking.

According to the latest recommendations of the French society of Hypertension blood pressure should focus on five classes of antihypertensive agents that demonstrated a prevention of cardiovascular complications in hypertensives.

Although Co morbidities often lead to guide the choices, in order of seniority, it comes of thiazide diuretics, beta blockers, calcium channel blockers, inhibitor (INHIBITOR of the ENZYME DE CONVERSION)-converting enzyme and angiotensin 2 receptor antagonists (ANGIOTENSIN 2 receptor ANTAGONIST).

(Co morbidity the antihypertensive choice)

Diabetes, renal INHIBITOR of converting ENZYME, receptor ANTAGONIST of ANGIOTENSIN 2 heart failure, diuretic, INHIBITOR of the ENZYME of CONVERSION, beta blocker.

Coronary artery disease-converting ENZYME, $\beta$-blocker blockers Atrial Fibrillation INHIBITOR) [51].

At the same time, The risk of malnutrition in hypertensives treated monotherapy was significantly different between five classes.

Ascending, beta-BLOCKERS, ANGIOTENSIN 2, converting ENZYME INHIBITOR, CI receptor ANTAGONIST.

Finally an increased risk of malnutrition is associated with diuretics, (Approximately three hypertensive on five treaties in a diuretic monotherapy, were at risk of malnutrition with an average score of the most mediocre MNA) Crogan and al had found similar results.

Among 266 residents over age 65 living in a retirement home, was one of the factors associated with undernutrition la taken diuretics $(\mathrm{p}=0.004)$ [52].

In the group treated with a beta-BLOCKER monotherapy, the risk of malnutrition was so low.

On the other hand, with a risk of malnutrition more or less identical, hypertension treated by an ANTAGONIST of RECEPTORS of the ANGIOTENSIN 2 seemed an average dem approaching the more than one nutritional state correct with less significant variations compared to the Group of hypertensive patients under beta BLOCKER.

In terms of cardiovascular risk The LIFE study [53] (2002), therapeutic randomized double-blind, has been shown in patients aged 55 to 80 years with LVH (mean age 70 years) and after about 5 years of follow-up, a greater reduction in cardiovascular events and including stroke, with a receptor ANTAGONIST of ANGIOTENSIN 2, as with beta blockers and this for a same drop in PA.

SCOPE study found a significant reduction in the cerebrovascular events in hypertensive patients aged over 
70 years treated by angiotensin receptor antagonist 2 [54] [55].

As in several testing superiority [54] [55], the ALLHAT study [56] published in 2002 found that a calcium channel blocker or a converting ENZYME INHIBITOR had the same effect on cardiovascular events in the subgroup of patients over 65 years of age.

The risk of malnutrition turned out to be less with converting enzyme inhibitors.

The probability to control hypertensive elderly patient with monotherapy is about $30 \%$. Most often it is useful to use the dual therapy to achieve pressure [57].

In 2006, the ENNS 2006 study showed that the pressure control was obtained by monotherapy in only a quarter of the population of treated hypertensives [58].

So SHEP (aged hypertensive subjects monitored for more than 4 years) indicates that $75 \%$ of patients should receive a combination of two drugs antihypertensives to achieve the objective of processing [59]. In the study HOT, $74 \%$ of patients in the group whose pressure is on average 140/80 mm Hg are treated with a combination of antihypertensive drugs [60].

For these older hypertensives, the risk of malnutrition was linked to the type of used dual.

The percentage of hypertension risk of malnutrition treated with free dual was significantly higher compared to hypertensive treated combined dual.

This trend is found in the recommendations of the ESC/ESH advocating the fixed-dose combinations in the treatment of hypertension because they" simplify treatment and promote compliance [61].

The choice of combinations of antihypertensive drugs is function of the associations known to be synergistic, additive.

It is recommended to start with a drug of the basket 2 (thiazide diuretics or calcium channel blocker). In case of need for a dual therapy, one can add a basket 1 drug (or ARBS or beta blocker-converting ENZYME INHIBITOR) [62].

The ARBS and converting ENZYME INHIBITOR association: to avoid because the ONTARGET study [63] [64] showed no superiority Anti hypertensive latter compared to converting ENZYME INHIBITOR alone, but more than kidney side effects. Moreover, no old hypertensive the did.

In the basket 1, and on comparing each association including converting ENZYME INHIBITOR for each association including the ANGIOTENSIN 2 receptor ANTAGONIST.

Converting ENZYME INHIBITOR proved to be more protective even though quite a few of them are incriminated in the foul which is much more common and potentially irreversible in aged hypertensives [65].

For hypertension treated with a beta-BLOCKER (with a risk of the lowest malnutrition monotherapy) associated with other classes of antihypertensives risk was strictly less than $50 \%$.

Furthermore, the converting enzyme inhibitor bitherapy and calcium channel blocker: ACCOMPLISH showed the superiority of this association versus the INHIBITOR of the ENZYME for CONVERSION and diuretic combination [66].

Test study in France, concluded that practitioners associate preferentially an ICA rather than a diuretic, using renal impairment as a determinant of choice in patients at cardiovascular risk [67].

Although several studies (Syst-Eur [68] and STOP [69] recommend the use of the Intercity or diuretics for the treatment of hypertension in the elderly, in the basket 2, it seems that the way of the IC is better because the percentage of hypertension a risk of malnutrition under association including an IC does not exceed the $50 \%$ unlike associations including a diuretic).

The HOT [70] and the Syst-Eur study [68] provide reassuring arguments screw blockers, they are now present in all the major recommendations. Recently amlodipine has demonstrated its interest in the ALLHAT study.

Finally, in the diabetic subject and the elderly, the superiority of the association INHIBITOR of the ENZYME for CONVERSION and thiazide diuretic versus placebo demonstrated by studies ADVANCE [71] and HYVET is discordant with the results found in the risk of malnutrition [48].

This association is among those that have the highest percentages of risk of malnutrition.

For hypertension treated with a diuretic (having the highest risk of malnutrition in monotherapy and the poorer MNA) associated with an IC, an INHIBITOR of the converting ENZYME, an ANTAGONIST of RECEPTORS of the ANGIOTENSIN 2 or beta-BLOCKER risk of malnutrition was greater than or equal to $50 \%$.

It seems, in view of the results that this class of antihypertensive agent should be handled with caution so that the pressure balance is synonymous with nutritional balance.

The Working Group HAS, in situations of the long treatment courses by diuretics, the risk of malnutrition in 
the elderly is not negligible [72].

Compliance can be defined as the degree of concordance between the conduct of an individual (in terms of making drug, followed by diet and lifestyle change) and the requirements or medical recommendations [73], or more simply the ability of a person to take a treatment according to a given prescription.

In literature, this term can be replaced by adhe difference, concordance or compliance [74].

In the group free dual the percentage of hypertension risk of malnutrition as antagonist of angiotensin 2/diuretic was almost twice and a half higher than treated dual combined by the same association.

Clinical studies have shown that the association AAII + diuretic is significantly more effective than each of the components taken separately [75]-[77].

Similarly, the percentage of hypertension risk of malnutrition treated by the INHIBITOR of the ENZYME of CONVERSION/diuretic association free dual was three times higher than treated dual combined by the same association.

This association is very well tolerated clinically.

All studies show that the INHIBITOR of the ENZYME CONVERSION + diuretic association is significantly more efficient in terms of decrease in the readings that each of the components taken separately [78]-[81].

Conversely, the percentage of hypertension a risk of malnutrition treated by the association receptor ANTAGONIST of ANGIOTENSIN 2/IC free dual seems less has the group treated by the same association combined dual (29.4\% vs. $45.5 \%)$ but this hypothesis remains to be confirmed because the Ods ratio was not for a true association between uses it has a dual free or combined and a possible risk of malnutrition.

The first therapeutic trials with this new fixed combination demonstrate some efficacy and good tolerability.

Contraindications to this new association are those related to each molecule taken separately [82].

In the case of triple therapy, rule HAS plans to associate the two drugs of the 2 (Diurétique thiazidique et inhibiteur calcique) basket and basket 1 drug (or ARBS or beta blocker-converting ENZYME INHIBITOR) and this outside specific situations such as co-morbidities cardiovascular (heart disease, disorders of rhythm, angina or heart failure), diabetes and violations of kidney, and particularly frequent iatrogenic risk in the elderly where the choice of treatment should be adapted [51].

In this context, the percentage of hypertension risk of malnutrition for the combination (INHIBITOR of CONVERSION the of ENZYME/IC/DIURETIC) was zero, but the number of patients was insufficient to infer a any conclusion ( $0.7 \%$ of all patients in the study).

On the other hand, i 1 seems the combination recommended by the HAS (diuretics thiazide and inhibitor calcium) basket 2 including 2 of basket 1 ANGIOTENSIN receptor ANTAGONIST was also the best in terms of risk of malnutrition with an average dem which is closest to correct nutritional status, and that the abandonment of the thiazide diuretics or calcium inhibitor increases see double the percentage of hypertension a risk of malnutrition.

Finally, one third of hypertension who were treated by a four were at risk of malnutrition, and more than half of them were over 70 years old with a low average dem (compared to monotherapy, dual and triple therapy).

What is particularly interested, is that all these hypertensives treated with a four that were risk of malnutrition had diabetes or Dyslipidemia.

The BEST study talks about the gap that exists between the recommendations of scientific bodies in cardiovascular prevention and what actually happens on the ground in high blood pressure and Dyslipidemia [83].

This finding is reinforced by the fact that the presence of a resistant hypertension, which justify the use of other additional antihypertensive agents for controlling these patients is probably a tipping their nutritional status.

\section{Conclusions}

The survey clearly shows that there is a risk of malnutrition in elderly patients of Sidi Bel Abbès; the latter is likely under estimated in hypertensives.

So the clinician must be more attentive to malnutrition because screening is not only easy but also a tool that we can act today on risk factors so that blood pressure can control rhymes with nutritional balance.

This is one of the particular challenges in the field of cardiovascular prevention.

In our country, the current period can be considered as a period in which public authorities should develop offensive strategies of prevention and struggle for control of the future nutritional situation. 


\section{References}

[1] ANAES (2003) Evaluation diagnostique de la dénutrition protéino-énérgetique des adultes hospitalisés. http://www.has-sante.fr/portail/upload/docs/application/pdf/denutrition recos $2006 \quad 09 \quad 25 \quad 14 \quad 20 \quad 46 \quad 375 . p d f$

[2] De groot, C., Van den broek, T. and Van staveren, W. (1999) Energy Intake and Micronutrient Intake in Elderly Europeans: Seeking the Minimum Requirement in the SENECA Study. Age Ageing, 28, 469-474.

[3] Constans, T., Alix, E. and Dardaine, V. (2000) Protein-Energy Malnutrition. Diagnostic Methods and Epidemiology. Presse Médicale, 29, 2171-2176.

[4] Alibhai, S.M., Greenwood, C. and Payette, H. (2005) An Approach to the Management of Unintentional Weight Loss in Elderly People. Canadian Medical Association Journal, 172, 773-780. http://dx.doi.org/10.1503/cmaj.1031527

[5] OMS/MSPRH (2005) Mesure des facteurs de risque des maladies non transmissibles dans deux wilayas pilotes en Algerie 2003 (Approche step wise de l’OMS, rapport final, Algerie).

[6] TAHINA (2007) Epidemiological Transition and Health Impact in North Africa. Enquete nationale santé. Transition épidémiologique et système de santé Projet TAHINA (Contrat No. ICA3-CT-2002-10011).

[7] Beck, A.M., Balknas, U.N., Furst, P., Hasunen, K., Jones, L., Keller, U., Melchior, J.C., Mikkelsen, B.E., Schauder, P., Sivonen, L., Zinck, O., Oien, H. and Ovesen, L. (2001) Food and Nutritional Care in Hospitals: How to Prevent Undernutrition-Report and Guidelines from the Council of Europe. Clinical Nutrition, 20, 455-460. http://dx.doi.org/10.1054/clnu.2001.0494

[8] ASPEN (2002) Guidelines for the Use of Parenteral and Enteral Nutrition in Adult and Pediatric Patients. Journal of Parenteral and Enteral Nutrition, 26, 1SA-138SA.

[9] Hasselmann, M. and Alix, E. (2003) Tools and Procedures for Screening for Undernutrition and Its Risk in Hospitals. Nutrition Clinique et Métabolisme, 17, 218-226. http://dx.doi.org/10.1016/j.nupar.2003.09.004

[10] Ramakrishnan, C. (2010) Establishment of a Nutrition Policy in Health Facilities. Screening for Undernutrition or Its Risk to the Admission and during Hospitalization Based on Simple Clinical Criteria. http://social-sante.gouv.fr/htm/dossiers/nutri hosp/rapport pdf/sommaire pdf.htm

[11] ESPEN, European Society of Parenteral and Enteral Nutrition (2002) Guidelines for Nutrition Screening. Clinical Nutrition, 22, 415-421.

[12] Correia, M.I. and Waitzberg, D.L. (2003) The Impact of Malnutrition on Morbidity, Mortality, Length of Hospital Stay and Costs Evaluated through a Multivariate Model Analysis. Clinical Nutrition, 22, 235-239. http://dx.doi.org/10.1016/S0261-5614(02)00215-7

[13] NNI, Nestlé Nutrition Institute (2013) Dépistage de la dénutrition aussi simple que le MNA. Manuel d’utilisation du Mini Nutritional Assessment (MNA $\left.{ }^{\circledR}\right)$. http://www.mna-elderly.com/forms/mna_guide_french.pdf

[14] Vellas, B., Villars, H., Abellan, G., Soto, M.E., Rolland, Y., Guigoz, Y., Morley, J.E., Chumlea, W., Salva, A., Rubenstein, L.Z. and Garry, P. (2006) Overview of the MNA-Its History and Challenges. The Journal of Nutrition Health and Aging, 10, 456-463; Discussion 463-465.

[15] Annie, Y., Vellas, B. and Garry, P.J. (1994) A Practical Assessment Tool for Grading the Nutritional State of Patients Elderly. Facts and Research in Gerontology, 4, 15-59.

[16] AFSSA (2009) Avis de l'agence francaise de la securité sanitaire des aliments sur l'évaluation des besoins nutritionnels des personnes agées fragiles ou atteintes de certaines pathologie afin de définir des références nutritionnelles permettant d'adapter leur prise en charge nutritionnelle. Saisine 2008-SA-0279. http://agriculture.gouv.fr/sites/minagri/files/documents/pdf/avis_AFSSA_2009_personnes_agees-2_cle815a59.pdf

[17] PNNS (2006) Livret d'accompagnement destiné aux professionnels de santé. Guide nutrition à partir de 55 ans. Guide nutrition pour les aidants des personnes âgées p 67. http://www.sante.gouv.fr/IMG/pdf/guide_pro_55ans.pdf

[18] Ricour, C. (2002) Mise en place d’une politique nutritionnelle dans les établissements de santé. Dépistage de la dénutrition ou son risque à l'admission et au cours de l'hospitalisation en se basant sur des critères cliniques simples. http://www.mangerbouger.fr/pro/IMG/pdf/RapportRicour-Nutritrion-EtablissementsSante.pdf

[19] ASPEN (2009) American Society for Parenteral and Enteral Nutrition. Clinical Guidelines for the Use of Parenteral and Enteral Nutrition in Adult and Pediatric Patients, 2009. Journal of Parenteral and Enteral Nutrition, 33, 255-259. http://dx.doi.org/10.1177/0148607109333115

[20] Spaccavento, S., Del Prete, M., Craca, A. and Fiore, P. (2009) Influence of Nutritional Status on Cognitive, Functional and Neuropsychiatric Deficits in Alzheimer’s Disease. Archives of Gerontology and Geriatrics, 48, 356-360. http://dx.doi.org/10.1016/j.archger.2008.03.002

[21] Torres, S.J., Mccabe, M. and Nowson, C.A. (2010) Depression, Nutritional Risk and Eating Behaviour in Older Caregivers. The Journal of Nutrition, Health \& Aging, 14, 442-448. http://dx.doi.org/10.1007/s12603-010-0041-x 
[22] Shenkin, A., Cederblad, G., Elia, M. and Isaksson, B. (1996) International Federation of Clinical Chemistry. Laboratory Assessment of Protein-Energy Status. Clinica Chimica Acta, 253, S5-S59.

http://dx.doi.org/10.1016/0009-8981(96)06289-4

[23] Ferry, M. (2006) Dénutrition de la personne âgée. Concours Médical, 128, 571-575.

[24] WHO (2006) International Classification of Adult Underweight, Overweight and Obesity According to BMI. http://apps.who.int/bmi/index.jsp?introPage=intro_3.html

[25] De Groot, C. and van Staveren, W. (2006) Undernutrition in the European-SENECA Studies. Clinics in Geriatric Medicine, 17, 699-708.

[26] Kuczmarski, M.F., Kuczmarski, R.J. and Najjar, M. (2000) Descriptive Anthropometric Reference Data for Older Americans. Journal of the American Dietetic Association, 100, 59-66. http://dx.doi.org/10.1016/S0002-8223(00)00021-3

[27] Payette, H., Coulombe, C., Boutier, V. and Gray-Donald, K. (2000) Nutrition Risk Factors for Institutionalization in a Free-Living Functionally Dependent Elderly Population. Journal of Clinical Epidemiology, 53, 579-587. http://dx.doi.org/10.1016/S0895-4356(99)00186-9

[28] Odlund Olin, A., Koochek, A., Ljungqvist, O. and Cederholm, T. (2005) Nutritional Status, Well-Being and Functional Ability in Frail Elderly Service Flat Residents. European Journal of Clinical Nutrition, 59, 263-270. http://dx.doi.org/10.1038/sj.ejcn.1602067

[29] Stratton, R.J., King, C.L., Stroud, M.A., Jackson, A.A. and Elia, M. (2006) "Malnutrition Universal Screening Tool” Predicts Mortality and Length of Hospital Stay in Acutely Ill Elderly. British Journal of Nutrition, 95, 325-330. http://dx.doi.org/10.1079/BJN20051622

[30] Donini, L.M., Poggiogalle, E., Piredda, M., Pinto, A., Barbagallo, M., Cucinotta, D. and Sergi, G. (2013) Anorexia and Eating Patterns in the Elderly. PLoS ONE, 8, e63539.

[31] Kergoat, M.J. (2000) Weight Loss in Elderly Residents in Nursing Homes and Extended Care Facilities. Revue Medicale de la Suisse Romande, 120, 853-861.

[32] Cynober, L., Alix, E., Arnaud-Battandier, F., Bonnefoy, M. and Brocker, P. (2001) Personnes âgées. In: Apports nutritionnels conseillés, Tec et Doc. Lavoisie, Paris.

[33] Ferry, M., Alix, E., Brocker, P., Constans, T., Lesourd, B. and Mischlich, D. (2002) Nutrition de la personne âgée. 2e édition, Masson, Paris.

[34] Crogan, N.L. and Pasvogel, A. (2003) The Influence of Protein-Calorie Malnutrition on Quality of Life in Nursing Homes. Journals of Gerontology Series A: Biological Sciences and Medical Sciences, 58, 159-164. http://dx.doi.org/10.1093/gerona/58.2.M159

[35] Margetts, B.M., Thompson, R.L., Elia, M. and Jackson, A.A. (2003) Prevalence of Risk of Undernutrition Is Associated with Poor Health Status in Older People in the UK. European Journal of Clinical Nutrition, 57, 69-74. http://dx.doi.org/10.1038/sj.ejcn.1601499

[36] Rocandio Pablo, A.M., Arroyo Izaga, M. and Ansotegui Alday, L. (2003) Assessment of Nutritional Status on Hospital Admission: Nutritional Scores. European Journal of Clinical Nutrition, 57, 824-831. http://dx.doi.org/10.1038/sj.ejcn.1601616

[37] Vasan, R.S., Beiser, A., Seshadri, S., Larson, M.G., Kannel, W.B., D’agostino, R.B. and Levy, D. (2002) Residual Lifetime Risk for Developing Hypertension in Middle-Aged Women and Men: The Framingham Heart Study. JAMA, 287, 1003-1010. http://dx.doi.org/10.1001/jama.287.8.1003

[38] Muurinen, M., Suominen, S., Routasalo, P., Suur-Uski, I. and Peiponen, I. (2005) Malnutrition and Associated Factors among Aged Residents in All Nursing Homes in Helsinki. European Journal of Clinical Nutrition, 59, 578-583. http://dx.doi.org/10.1038/sj.ejcn.1602111

[39] Ventose, R., Macintosh, C., Callary, M., Penhall, R., Horowitz, M. and Chapman, I. (2003) The Nutritional Status of 250 Older Australian Containers of Domiciliary Care Services and Its Association with Outcomes at 12 Months. Journal of the American Geriatrics Society, 51, 1007-1011. http://dx.doi.org/10.1046/j.1365-2389.2003.51317.x

[40] Archana Singh-Manoux Inserm, Unit 1018, Centre for Research in Epidemiology and Population Health Cohorts at the International Level (2012) History and Perspective, adsp No. 78, 31-33.

[41] ESPEN, European Society of Parenteral and Enteral Nutrition (2003) ESPEN Guidelines for Nutrition Screening 2002. Clinical Nutrition, 22, 415-421. http://dx.doi.org/10.1016/S0261-5614(03)00098-0

[42] Pare, W., Herrmann, F., Quad, P., Fragiacomo, C., Annie, Y. and Rapin, C. (2000) Assessment of Nutritional Status in Hospitalized Elderly and Potentially Non-Geographical Population Malnourish, and Relationship with the Costs and Duration of Hospitalization. Age and Nutrition, 11, 13-20.

[43] Beautiful, P.E., Kaffy Kull, F.S. and Ingrand, P. (2001) Undernutrition Is an Independent Risk Factor of Early Com- 
plications after Insertion of a Percutaneous Gastrostomy Endoscopic. Gastroentérologie Clinique et Biologique, 25, 891-895.

[44] Vellas, B., Guigoz, Y., Garry, P.J., Nourhashemi, F., Bennahum, D., Lauque, S. and Albarede, J.L. (1999) The Mini Nutritional Assessment (MNA) and Its Use in Grading the Nutritional State of Elderly Patients. Nutrition, 15, 116-122. http://dx.doi.org/10.1016/S0899-9007(98)00171-3

[45] Doucet, J. and Otero, G. (2003) Drug Consumption in the Elderly. Care Gerontology, 40, 16-18.

[46] Kiledjian, E., Baumgartner-Bonnevay, C., Derharoutunian, C. and Garreau, I. (2003) Prevent the Drug Supply in the Elderly. Care Gerontology, 40, 19-23.

[47] Ferry, M., Alix, E., Brocker, P., Constans, T. and Lesourd, D. (2002) Old Quiz Nutrition. MASSON, Paris.

[48] Beckett, N.S., Peters, R., Fletcher, A.E., Staessen, J.A., Liu, L., Dumitrascu, D., Stoyanovsky, V., Antikainen, R.L., Nikitin, Y., Anderson, C., Belhani, A., Forette, F., Rajkumar, C., Thijs, L., Banya, W. and Bulpitt, C.J. (2008) Treatment of Hypertension in Patients 80 Years of Age or Older. The New England Journal of Medicine, 358, $1887-1898$. http://dx.doi.org/10.1056/NEJMoa0801369

[49] Newman, A.B., Yáñez, D., Harris, T., Duxbury, H., Enright, P.L. and Fried, L.P. (2001) Weight Changes in Old Age and Its Association with Mortality. Journal of the American Geriatrics Society, 49, 1309-1318. http://dx.doi.org/10.1046/j.1532-5415.2001.49258.x

[50] Staessen, J.A., Gasowski, J., Wang, J.G., Thijs, L., Den Hond, E., Boissel, J.P., Coope, J., Ekbom, T., Gueyffier, F., Liu, L., Kerlikowske, K., Pocock, S. and Fagard, R.H. (2000) Risks of Untreated and Treated Isolated Systolic Hypertension in the Elderly: Meta-Analysis of Outcome Trials. The Lancet, 355, 865-872. http://dx.doi.org/10.1016/S0140-6736(99)07330-4

[51] Blacher, J., Halimi, J.M., Hanon, O., Mourad, J.J., Pathak, A., Schnebert, B. and Girerd, X. (2013) Management of Arterial Hypertension in Adults: 2013 Guidelines of the French Society of Arterial Hypertension. Presse Médicale, 42, 819-825. http://dx.doi.org/10.1016/j.lpm.2013.01.022

[52] Crogan, N.L., Corbett, C.F. and Short, R.A. (2002) The Minimum Data Set: Predicting Malnutrition in Newly Admitted Nursing Home Residents. Clinical Nursing Research, 11, 341-353. http://dx.doi.org/10.1177/105477380201100308

[53] Dahlof, B., Devereux, R.B., Kjeldsen, S.E., Julius, S., Beevers, G., De Faire, U., Fyhrquist, F., Ibsen, H., Kristiansson, K., Lederballe-Pedersen, O., Lindholm, L.H., Nieminen, M.S., Omvik, P., Oparil, S. and Wedel, H. (2002) Cardiovascular Morbidity and Mortality in the Losartan Intervention for Endpoint Reduction in Hypertension Study (LIFE): A Randomised Trial against Atenolol. The Lancet, 359, 995-1003. http://dx.doi.org/10.1016/S0140-6736(02)08089-3

[54] Lithell, H., Hansson, L., Skoog, I., Elmfeldt, D., Hofman, A., Olofsson, B., Trenkwalder, P. and Zanchetti, A. (2003) The Study on Cognition and Prognosis in the Elderly (SCOPE): Principal Results of a Randomized Double-Blind Intervention Trial. Journal of Hypertension, 21, 875-886. http://dx.doi.org/10.1097/00004872-200305000-00011

[55] Papademetriou, V., Farsang, C., Elmfeldt, D., Hofman, A., Lithell, H., Olofsson, B., Skoog, I., Trenkwalder, P. and Zanchetti, A., Study on Cognition and Progress in the Elderly Study Group (2004) Stroke Prevention with Angiotensin II Type 1 Receptor Blocker Candesartan in Elderly Patients with Isolated Systolic Hypertension: The Study on Cognition and Prognosis in the Elderly (SCOPE). Journal of the American College of Cardiology, 44, 1175-1180. http://dx.doi.org/10.1016/j.jacc.2004.06.034

[56] ALLHAT, The Allhat Officers Coordinators for the Allhat Collaborative Research Group (2002) Major Outcomes in High-Risk Hypertensive Patients Randomized to Angiotensin-Converting Enzyme Inhibitor or Calcium Channel Blocker vs. Diuretic: The Antihypertensive and Lipid-Lowering Treatment to Prevent Heart Attack Trial (ALLHAT). JAMA, 288, 2981-2997. http://dx.doi.org/10.1001/jama.288.23.2981

[57] Hamilton, O. (2009) Hypertension in the Elderly: Particularities and Precautions. Presse Médicale, 38, 614-620.

[58] Godet-Thobie, H., Vernay, M., Noukpoape, A., et al. (2008) Mean Arterial Pressure and Blood Pressure among Adults Aged 18 to 74 Years. ENNS, 2006-2007. Bulletin-EPID Epidemiological Weekly, No. 49.

[59] SHEP (1991) Prevention of Stroke by Antihypertensive Drug Treatment in Older Persons with Isolated Systolic Hypertension. Final Results of the Systolic Hypertension in the Elderly Program (SHEP). JAMA, 265, 3255-3264. http://dx.doi.org/10.1001/jama.1991.03460240051027

[60] Hansson, L., Zanchetti, A., Carruthers, S.G., Dahlof, B., Elmfeldt, D., Julius, S., Menard, J., Rahn, K.H., Wedel, H. and Westerling, S. (1998) Effects of Intensive Blood-Pressure Lowering and Low-Dose Aspirin in Patients with Hypertension: Principal Results of the Hypertension Optimal Treatment (HOT) Randomised Trial. The Lancet, 351, 1755-1762. http://dx.doi.org/10.1016/S0140-6736(98)04311-6

[61] Mancia, G., Laurent, S., Agabiti-Rosei, E., Ambrosioni, E., Burnier, M., Caulfield, M.J., Cifkova, R., Clement, D., Coca, A., Dominiczak, A., Erdine, S., Fagard, R., Farsang, C., Grassi, G., Haller, H., Heagerty, A., Kjeldsen, S.E., 
Kiowski, W., Mallion, J.M., Manolis, A., Narkiewicz, K., Nilsson, P., Olsen, M.H., Rahn, K.H., Redon, J., Rodicio, J., Ruilope, L., Schmieder, R.E., Struijker-Boudier, H.A., Van Zwieten, P.A., Viigimaa, M. and Zanchetti, A. (2009) Reappraisal of European Guidelines on Hypertension Management: A European Society of Hypertension Task Force Document. Journal of Hypertension, 27, 2121-2158. http://dx.doi.org/10.1097/HJH.0b013e328333146d

[62] Girerd, X., Hanon, O. and Babici, D. (2002) Choix raisonné du deuxième antihypertenseur après échec d'une première monothérapie: La stratégie des paniers thérapeutiques. Archives des maladies du coeur et des vaisseaux, 95, 723-726.

[63] Yusuf, S., Teo, K. and Pogue, J. (2008) Telmisartan, Ramipril, or Both in Patients at High Risk for Vascular Events. New England Journal of Medicine, 358, 1547-1559. http://dx.doi.org/10.1056/NEJMoa0801317

[64] Fagar, R., ONTARGET Investigators (2009) Prognostic Value of Blood Pressure in Patients with High Vascular Risk in the Ongoing Telmisartan Alone and in Combination with Ramipril Global Endpoint Trial Study. Journal of Hypertension, 27, 1360-1369. http://dx.doi.org/10.1097/HJH.0b013e32832d7370

[65] Bouteloup, V. (2005) Polypharmacy and Feed Intake. Clinical Nutrition and Metabolism, 19, 20-24. http://dx.doi.org/10.1016/j.nupar.2005.01.004

[66] Jamerson, K., Weber, M.A., Bakris, G.L., Dahlof, B., Pitt, B., Shi, V., Hester, A., Gupte, J., Gatlin, M. and Velazquez, E.J. (2008) Benazepril plus Amlodipine or Hydrochlorothiazide for Hypertension in High-Risk Patients. The New England Journal of Medicine, 359, 2417-2428. http://dx.doi.org/10.1056/NEJMoa0806182

[67] Vaisse, B., Girerd, X. and Pouchain, D. (2009) L'étude CRITERE, Usage des combinaisons fixes d'antihypertenseurs comportant un inhibiteur du système rénine-angiotensine. Analyse des pratiques médicales en France, p. 8.

[68] Staessen, J.A., Fagard, R., Thijs, L., Celis, H., Arabidze, G.G., Birkenhager, W.H., Bulpitt, C.J., De leeuw, P.W., Dollery, C.T., Fletcher, A.E., Forette, F., Leonetti, G., Nachev, C., O’brien, E.T., Rosenfeld, J., Rodicio, J.L., Tuomilehto, J. and Zanchetti, A., The Systolic Hypertension in Europe (Syst-Eur) Trial Investigators (1997) Randomised Double-Blind Comparison of Placebo and Active Treatment for Older Patients with Isolated Systolic Hypertension. The Lancet, 350, 757-764. http://dx.doi.org/10.1016/S0140-6736(97)05381-6

[69] Ekbom, T., Dahlof, B., Hansson, L., Lindholm, L.H., Schersten, B. and Wester, P.O. (1992) Antihypertensive Efficacy and Side Effects of Three Beta-Blockers and a Diuretic in Elderly Hypertensives: A Report from the STOP-Hypertension Study. Journal of Hypertension, 10, 1525-1530. http://dx.doi.org/10.1097/00004872-199210120-00013

[70] Hansson, L., Zanchetti, A., Carruthers, S.G., Dahlof, B., Elmfeldt, D., Julius, S., Menard, J., Rahn, K.H., Wedel, H. and Westerling, S. (1998) Effects of Intensive Blood-Pressure Lowering and Low-Dose Aspirin in Patients with Hypertension: Principal Results of the Hypertension Optimal Treatment (HOT) Randomised Trial. The Lancet, 351, 1755-1762. http://dx.doi.org/10.1016/S0140-6736(98)04311-6

[71] Patel, A., MacMahon, S. and Chalmers, J., ADVANCE Collaborative Group (2007) Effects of a Fixed Combination of Perindopril and Indapamide on Macrovascular and Microvascular Outcomes in Patients with Type 2 Diabetes Mellitus (The ADVANCE Trial): A Randomized Controlled Trial. The Lancet, 370, 829-840. http://dx.doi.org/10.1016/S0140-6736(07)61303-8

[72] HAS (2007) Stratégie de prise en charge en cas de dénutrition protéino-énergetique chez la personne agée. http://www.has-sante.fr/portail/upload/docs/application/pdf/synthese_denutrition_personnes_agees.pdf

[73] Vieira-Teixheira, J.J., Lin, F., Cardoso de Castro, L.L., et al. (2000) Drug Compliance and the Elderly: Who Is Publishing, Where, and When? CAD Saúde Pública, 16, 139-144. http://dx.doi.org/10.1590/S0102-311X2000000100014

[74] Snowden, A. (2008) Medication Management in Older Adults: A Critique of Concordance. British Journal of Nursing, 2, 114-119. http://dx.doi.org/10.12968/bjon.2008.17.2.28140

[75] Ezequiel, B. and Blair, J. (2002) Candesartan Cilexetil More Hydrochlorothiazide Combination. Drugs, 62, 787-816. http://dx.doi.org/10.2165/00003495-200262050-00006

[76] Philipp, T., et al. (1997) Dose-Finding Study of Candesartan More Hydrochlorothiazide in Patients with Mild to Moderate Hypertension. Journal of Human Hypertension, 2, S67-S68.

[77] Oparil, S. (1999) Candesartan in Combination with Low-Dose Hydrochlorothiazide Is Effective in Severe Hypertension. American Journal of Cardiology, 84, 35-41. http://dx.doi.org/10.1016/S0002-9149(99)00732-8

[78] Murray, N.B. (1991) Review of International Safety Data for Lisinopril-Hydrochlorothiazide Combination Treatment. Journal of Human Hypertension, 5, 63-68.

[79] Hart, W. (1991) Lisinopril-Hydrochlorothiazide Combination Compared with the Monocomponents in Hypertensive Elderly Patients. Journal of Human Hypertension, 5, 85-89.

[80] Kohler, J., Kampfner, G. and Low, A. (1995) Efficacy and Safety of a Fixed-Dose Combination of Lisinopril and Hydrochlorothiazide: Results of a Drug Monitoring Study in 5840 Patients. Drug Development Research, 2, 34-37.

[81] Vaisse, B., et al. (1993) Evaluation of the Antihypertensive Efficacy of Lisinopril and Captopril Associated Hydroch- 
lorothiazide with Ambulatory Blood Pressure Measurement. Annals of Cardiology and Angiology, 42, 566-572.

[82] Krzesinski, M.J. (2007) SCHEEN the Drug of the Month EXFORGE®: First Association of a Calcium Antagonist (Amlodipine Besylate) and an Inhibitor of Angiotensin II (Valsartan) Receptor. Revue Médicale de Liège, 62, 688-694.

[83] Bradley, D.J., Powe, N.R. and Baughman, K.L. (2002) Impact of BEST and COPERNICUS on Overall Estimates of Beta-Blocker Survival Benefit in Heart Failure: An Updated Meta-Analysis of Randomized Trials (Abstract). Journal of the American College of Cardiology, 39, 156. http://dx.doi.org/10.1016/S0735-1097(02)80689-1

[84] Assmann, G., et al. (1992) Relationship of High Density Lipoprotein Cholesterol and Triglycerides to Incidence of Atherosclerotic Coronary Artery Disease (PROCAM). American Journal of Cardiology, 70, 733-737. http://dx.doi.org/10.1016/0002-9149(92)90550-I

\section{Abbreviations}

quadrithérapie $=$ quadruple therapy

BB: beta blockers

IEC or Inhibitor of the enzyme of conversion: ACE inhibitor

ARA 2, or angiotensin 2 receptor antagonists: receptor antagonists of angiotensinogen 2

IC or CI: calcium channel blockers 